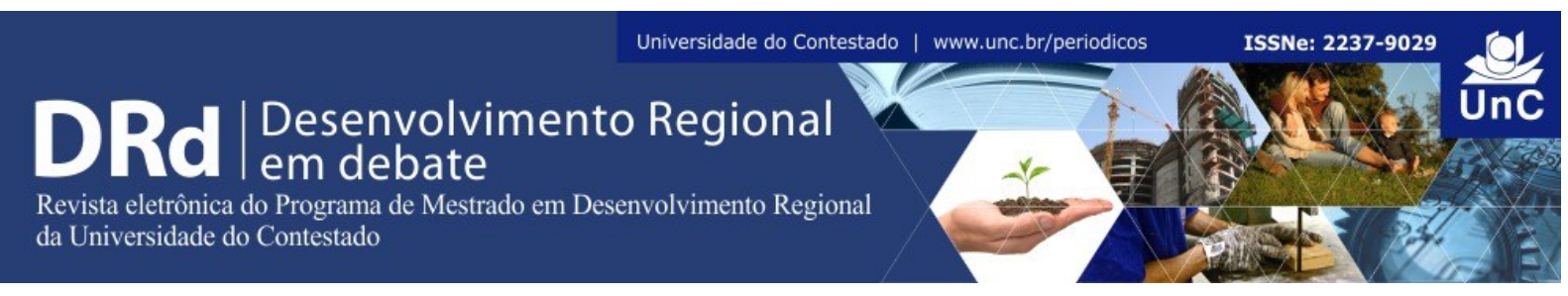

\title{
COMUNICAÇÃO PÚBLICA E ACESSO À INFORMAÇÃO NA GESTÃo MUNICIPAL: UM ESTUDO EM CAMPOS DOS GOYTACAZES-RJ
}

\author{
Juliana Lima Gomes Cardoso ${ }^{1}$ \\ Denise Cunha Tavares Terra ${ }^{2}$ \\ Ludmila Gonçalves da Matta
}

\begin{abstract}
RESUMO
Este trabalho tem por objetivo analisar as práticas de comunicação pública implementadas pela Prefeitura de Campos dos Goytacazes-RJ, município este considerado o maior produtor de petróleo do Brasil e, em consequência, o maior recebedor de royalties e participações especiais. O estudo buscou observar, por meio de uma revisão teórica sobre Comunicação Pública e dos materiais produzidos pela Secretaria Municipal de Comunicação Social, se o órgão cumpre seu papel na área da Comunicação Pública, no que tange, principalmente, ao direito de acesso à informação por parte do cidadão. Como caminho metodológico, esta pesquisa quali-quantitativa contou com a aplicação de questionário ao gestor da área de comunicação do município e, também, com a análise de conteúdo das notícias veiculadas no site oficial da Prefeitura. Foi analisado um universo de 2.535 (duas mil quinhentas e trinta e cinco) notícias publicadas no período de janeiro a junho de 2013. Como resultado, verificouse um interesse predominante da Prefeitura de Campos dos Goytacazes por apresentar e promover os serviços da administração e seus gestores e uma acanhada prática de Comunicação Pública, no que diz respeito a abastecer o cidadão com informações para que ele usufrua melhor dos serviços ofertados e possa integrar o processo decisório que acompanha a prática política.
\end{abstract}

Palavras-chave: Comunicação Pública. Gestão Pública. Informação.

\footnotetext{
${ }^{1}$ Jornalista no Instituto Federal Fluminense (IFF). Mestranda do Curso em Planejamento Regional e Gestão de Cidades da Universidade Candido Mendes. Campos-RJ. Brasil. E-mail: julianalima@iff.edu.br

${ }^{2}$ Economista com Mestrado em Ciência Política pelo Iuperj e Doutorado em Geografia pela UFRJ. Professora/pesquisadora do Curso de Mestrado em Planejamento Regional e Gestão de Cidades da Universidade Candido Mendes. Campos-RJ. Brasil. E-mail: deniseterra@gmail.com

${ }^{3}$ Possui graduação em Ciências Sociais pela Universidade Estadual do Norte Fluminense Darcy Ribeiro (2002), graduação em Serviço Social pela Universidade Norte do Paraná (2010), mestrado em Políticas Sociais pela Universidade Federal Fluminense (2005) e doutorado em Sociologia Política pela Universidade Estadual do Norte Fluminense Darcy Ribeiro (2012). Atualmente é professora da Universidade Cândido Mendes. Tem experiência na área de Políticas Públicas. Universidade Candido Mendes. Campos-RJ. Brasil. E-mail: ludmatta2014@gmail.com
}

DRd - Desenvolvimento Regional em debate (ISSNe 2237-9029)

v. 5, n. 1, p. 38-69, jan./jun. 2015. 


\title{
PUBLIC COMMUNICATION AND ACCESS TO INFORMATION IN THE MUNICIPAL MANAGEMENT: A CASE STUDY IN CAMPOS DOS GOYTACAZES- RJ
}

\begin{abstract}
This paper aims to examine the practices of public communication implemented by the City Hall of Campos of Goytacazes-RJ, municipality considered the largest oil producer in Brazil, therefore, the greatest recipient of royalties and special participation. The study intended to analyse, by means of a theoretical review of Public Communication and materials produced by the Municipal Secretariat of Social Communication, if the entity performs its role in the area of Public Communication, regarding, mainly, the right of access to information by citizens. As a methodological way, this quali-quantitative research included the application of a questionnaire to the manager of the communication area of the municipality, and also the content analysis of the news published on the official website of the City Hall. A number of 2,535 (two thousand five hundred and thirty-five) news published in the period from January to June 2013 was analyzed. As a result, there was a predominant interest of the City Hall of Campos dos Goytacazes in presenting and promoting the services of the administration and management and a still small practice of Public Communication practice with regard to supply the citizens with information so that they make better use of the services offered and integrate the decision-making process that accompanies political practice.
\end{abstract}

Keywords: Public Communication. Public Management. Information.

\section{INTRODUÇÃO}

No Brasil, o direito de acesso à informação pública foi previsto na Constituição Federal de 1988, no inciso XXXIII do Capítulo I - dos Direitos e Deveres Individuais e Coletivos - que dispõe que:

\footnotetext{
Todos têm direito a receber dos órgãos públicos informações de seu interesse particular, ou de interesse coletivo ou geral, que serão prestadas no prazo da lei, sob pena de responsabilidade, ressalvadas aquelas cujo sigilo seja imprescindível à segurança da sociedade e do Estado (DIÁRIO OFICIAL DA UNIÃO, p. 1).
}

A Constituição também aborda sobre o acesso à informação pública no Art. $5^{\circ}$, inciso XIV, Art. 37, $\S 3^{\circ}$, inciso II e no Art. 216, $\S 2^{\circ}$. Em suma, estes são os dispositivos que a nova Lei de Acesso à Informações (LAI) regulamenta, estabelecendo requisitos mínimos para a divulgação de informações públicas e procedimentos para facilitar e agilizar o acesso do cidadão em três instâncias: federal, estadual e municipal. Sancionada pela Presidente da República, Dilma Rousseff, em 18 de novembro de 2011, a Lei $\mathrm{N}^{\mathrm{o}} 12.527$ passou a vigorar no dia 16 de maio de 2012 e é um importante passo para a consolidação democrática do Brasil, assim como para o sucesso das ações de prevenção da corrupção no país. Por tornar possível uma maior participação popular e o controle social das ações governamentais, entende-se que o acesso da sociedade às informações públicas pode contribuir para uma melhoria na gestão pública. 
O conceito de Comunicação Pública ganhou relevância no Brasil na década de 1990, a partir dos estudos feitos pelo autor francês Pierre Zémor ${ }^{4}$, que teve seu livro $L a$ Communication Publique (1995) traduzido no Brasil pela autora Elizabeth Pazito Brandão. Brandão (2009, p. 12), destaca que "o crescimento das assessorias pode ser apontado como um dos fatores motivacionais para o desenvolvimento do conceito de Comunicação Pública". Mas, de um modo geral, percebe-se que as assessorias produzem releases para divulgar as ações administrativas e promover seus gestores, deixando de lado os princípios da Comunicação Pública e o interesse da população pela gestão pública.

Assim, este estudo tem como objetivo analisar as práticas de comunicação da Prefeitura de Campos dos Goytacazes, verificando se o município informa e dialoga questões de interesse público com a população. Essa investigação teve como objetivos específicos: verificar as estratégias/ferramentas de comunicação, utilizadas pela instituição, que permitem espaços de participação e diálogo com o cidadão; analisar e categorizar as informações veiculadas em forma de notícias, publicadas no site oficial da prefeitura, no âmbito da Comunicação Pública; comparar o volume de informação com o volume de recurso destinado pela Prefeitura de Campos dos Goytacazes para cada setor.

Para a elaboração do referencial teórico foi necessária uma convergência entre várias áreas do conhecimento, com reflexões sobre os conceitos de Comunicação Pública, Gestão Pública, Acesso à Informação e Participação. Por meio de uma abordagem quali-quantitativa, a pesquisa fez um estudo de caso por análise de conteúdo das notícias veiculadas no site oficial da Prefeitura de janeiro a junho de 2013 e aplicamos um questionário ao Secretário de Comunicação do Município. Com isso, o trabalho conseguiu traçar as atribuições, condições de funcionamento, recursos humanos e materiais da Secretaria de Comunicação Social (Secom) da Prefeitura de Campos dos Goytacazes, as estratégias de comunicação utilizadas pela instituição e as informações passadas para a população em forma de notícia.

\section{ACESSO À INFORMAÇÃO EM CAMPOS DOS GOYTACAZES}

Para compreendermos melhor o objeto de estudo é necessário um breve histórico do Município de Campos dos Goytacazes. Com uma área de $4.027 \mathrm{~km}^{2}$ este é o maior Município do Estado do Rio de Janeiro em extensão territorial, e o décimo município em população no interior do Brasil com 463.731 habitantes ${ }^{5}$. O crescimento da população dos municípios que compõem a Região Norte Fluminense (onde se localiza o Município em estudo) pode ser verificada a partir da tabela 1 :

\footnotetext{
4 Presidente da Federação Europeia de Comunicação Pública e fundador presidente da Associação Francesa de Comunicação Pública.

${ }^{5}$ Dados do Censo IBGE 2010.
} 
Tabela 1 - Evolução populacional da Região Norte Fluminense entre 2000 e 2010.

\begin{tabular}{lccc}
\hline \multirow{2}{*}{ Município } & \multicolumn{2}{c}{ Ano } & Crescimento \\
\cline { 2 - 4 } & 2000 & 2010 & $13,9 \%$ \\
\hline Campos dos Goytacazes & 406.989 & 463.545 & $54,0 \%$ \\
Carapebus & 8.666 & 13.348 & $-0,4 \%$ \\
Cardoso Moreira & 12.595 & 12.540 & $12,9 \%$ \\
Conceição de Macabu & 18.782 & 21.200 & $56,1 \%$ \\
Macaé & 132.461 & 206.748 & $48,0 \%$ \\
Quissamã & 13.674 & 20.244 & $2,1 \%$ \\
São Fidélis & 36.789 & 37.553 & $0,5 \%$ \\
São Francisco do Itabapoana & 41.145 & 41.357 & $18,4 \%$ \\
São João da Barra & 27.682 & 32.767 & \\
\hline Fonto: IBGE (2000/2010) & & & \\
\hline
\end{tabular}

Fonte: IBGE (2000/2010)

O crescimento elevado da população de muitos municípios dessa Região pode ser explicado pelo ciclo atual de desenvolvimento econômico que a Região vem passando a partir da economia do petróleo. A história do desenvolvimento econômico da Região e do Município é marcada por três grandes ciclos econômicos, um no século XIX, com a agroindústria açucareira, outro no início século XX e por fim um ciclo que se inicia no final do século XX e inicio do XXI. De acordo com Carvalho e Silva (2004), o primeiro ciclo de crescimento foi caracterizado pelo aumento da produção açucareira com base nas usinas a vapor. O segundo ciclo foi caracterizado pela consolidação de grandes plantas industriais em moldes capitalistas, as usinas, que entram em declínio no final do século XX, quando surge um novo ciclo de crescimento econômico na Região, com as atividades de exploração e produção de petróleo na Bacia de Campos.

A Bacia de Campos é responsável por mais de $80 \%$ da produção nacional de petróleo. O Município possui uma vultosa arrecadação advinda dos Royalties e Participação Especial (arrecadou R \$ 1.375.983.824,37 em 2013 ${ }^{6}$, Inforoyalties). Atualmente as principais atividades econômicas, além da extração de petróleo e gás, são as indústrias de transformação, comércio varejista, construção civil, prestação de serviços e agropecuária. A cidade também se destaca por ser um importante polo universitário e cerâmico do estado, com 143 empresas em funcionamento (Rede Campos Cerâmica).

Os principais acessos ao Município são pelas BR 101 e BR 356, que cortam a cidade, ligando o Município aos estados de Minas Gerais e Espírito Santo. Outro é pela RJ 216, na direção do litoral-, Campos dos Goytacazes está situado em um rede que favorece à circulação de informação.

Além disso, o fluxo de informações tende a se tornar ainda mais importante com o processo de reestruturação que a Região Norte Fluminense está passando, em função dos grandes investimentos, como o Complexo Portuário do Açu e o Complexo Logístico e Portuário Farol/Barra do Furado, que estão alterando a dinâmica regional e as relações entre os municípios.

O Município possui três jornais impressos, sendo dois de maior circulação local e regional, O Diário e Folha da Manhã; 13 canais de radiodifusão e 14 empresas de TV, RTV, GTVD. Das emissoras de TV, três tem caráter regional e com maior abrangência. São elas:

${ }^{6}$ Valores Reais (corrigidos pelo IGP-DI de Abril de 2014). 
Inter TV, TV Record e SBT. É nesse contexto que se torna importante trazer o debate sobre os instrumentos que tratam do acesso à informação pública no Município de Campos dos Goytacazes.

Assim, esta pesquisa começa com a análise inicial da Lei Orgânica do Município ${ }^{7}$ (LOM), que é o conjunto de normas que regem o município e onde estão definidas as atribuições dos Poderes e dos órgãos, bem como os deveres e os direitos dos cidadãos. Na Lei Orgânica está previsto, em seu Capítulo II, Artigo 93 que:

Todo o órgão ou entidade municipal prestará aos interessados, no prazo de quinze dias úteis, e sob pena de responsabilidade funcional, as informações de interesse particular, coletivo ou geral, ressalvadas aquelas cujo sigilo seja imprescindível, como tais definidas em lei (LOM, 1990).

Ainda de acordo com a LOM, a publicidade dos atos, programas, obras, serviços e campanhas dos órgãos ou entidades municipais devem ter caráter educativo, informativo ou de orientação social, dele não podendo constar nomes, símbolos ou imagens que caracterizem promoção pessoal de autoridades ou funcionários públicos municipais. Em seu artigo 94, a lei prevê que a publicação das leis e atos municipais será feita no Diário Oficial do Município, e, na falta deste, em órgão da imprensa local.

É importante lembrar ainda que O Diário Oficial do município é um documento legítimo que publica as decisões legais determinadas e tomadas pela Prefeitura da cidade. Porém, é um instrumento de divulgação que não faz parte do hábito de leitura do cidadão. No Município em questão o Diário Oficial está disponível no site oficial da Prefeitura, conforme Figura 1. Na lei, está previsto que a escolha do órgão de imprensa para divulgação das leis e atos administrativos se dará por meio de licitação, em que serão levados em conta não só as condições de preços como as circunstâncias de frequência, horário, tiragem e distribuição.

${ }^{7}$ Lei s/n de 28/03/90 - Lei Orgânica do Município de Campos dos Goytacazes. Disponível em: $<$ http://www.campos.rj.gov.br/listaLeis.php>. Acesso em: 07 jul. 2013. 
Figura 1- Página inicial do Diário Oficial do Município de Campos dos Goytacazes.

\begin{tabular}{|c|c|}
\hline \multicolumn{2}{|c|}{ Bom dia! Terça, 17 de setembro de 2013} \\
\hline \multicolumn{2}{|l|}{ Prefeitura } \\
\hline \multicolumn{2}{|r|}{ - Diario Oficial Antigo } \\
\hline \multicolumn{2}{|l|}{ Leis Municipais } \\
\hline Licitações & L. Diário Oficial de 17 de Setembro de 2013-P- I a VI \\
\hline E. Diário 0ficialde 16 de Setembre de 2013-P La VI & L Diário Oficial de 16 de Setembro de 2013-P- I a VI \\
\hline Plano Diretor & $\mathcal{L}$ \\
\hline \multicolumn{2}{|r|}{ L Diário Oficial de 13 de Setembro de 2013-P- I a IX } \\
\hline \multicolumn{2}{|r|}{ L Diário Oficial de 12 de Setembro de 2013-P- I a XII } \\
\hline \multicolumn{2}{|r|}{ L Diário Oficial de 11 de Setembro de 2013-P- I a VIII } \\
\hline \multicolumn{2}{|l|}{ Telefones Úteis } \\
\hline \multicolumn{2}{|l|}{ Logos/Hinos/Manual } \\
\hline Fale Conosco & 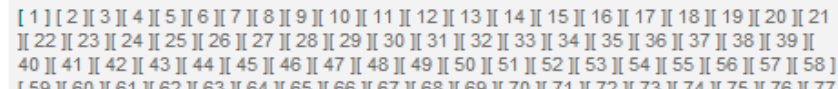 \\
\hline Notícias & 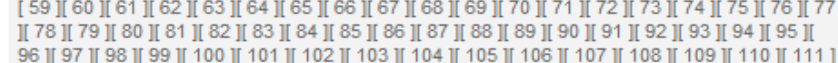 \\
\hline Destaques & [ 112 ][ 113 ][ 114 ][ 115 ][ 116 ][ 117 ][ 118 ][ 119 ][ 120 ][ 121 ][ 122 ][ 123 ][ 124 ][ 125 ][ 126 ] \\
\hline Categoria de Notícias & 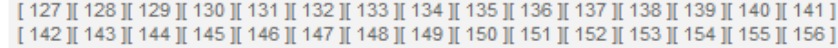 \\
\hline Últimas Noticias & 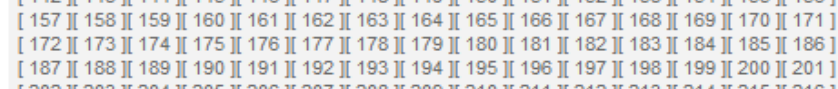 \\
\hline $\begin{array}{l}\text { Manual } \\
\text { de Auditoria Interna } \\
\text { - Clique aqui - }\end{array}$ & 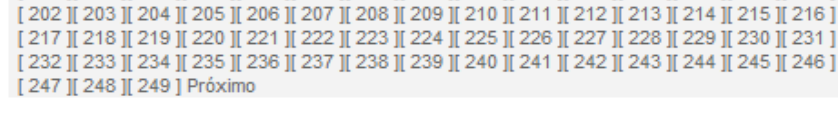 \\
\hline
\end{tabular}

Fonte: www.campos.rj.gov.br.

Antes de o Diário Oficial do Municipal ficar disponível no site da Prefeitura, o Diário ficou, por mais de 100 anos, sob a responsabilidade do Jornal Monitor Campista, o terceiro jornal mais antigo do Brasil, com 175 anos de existência, até o fechamento no dia 15 de novembro de 2009. A empresa Diários Associados, mantenedora do jornal, informou em entrevista ${ }^{8}$ realizada no dia 17 de novembro de 2009, por meio do presidente da empresa, Maurício Dinepi, que o fechamento do jornal foi motivado pelo fim da publicação do Diário Oficial da Prefeitura de Campos dos Goytacazes. A publicação do Diário Oficial correspondia a 50\% da receita do veículo. O informativo da Prefeitura foi retirado do jornal após a Justiça alegar que não havia licitação para a publicação no Monitor Campista e que o Diário Oficial deveria ser aberto à concorrência de outros veículos, por meio de licitação. A Justiça atendeu a uma ação movida pelo Grupo Folha da Manhã contra o Monitor Campista.

Como o Diário Oficial da Prefeitura fica disponível no site da Prefeitura fizemos um levantamento estatístico para verificar o alcance das informações aos cidadãos. De acordo com o Censo de 2010 do IBGE, conforme ilustra o Gráfico 1, 97\% das residências no Município possuem TV, contra 85\% em relação ao Censo de 2000. Também em 2010, 38\% das residências tinham computador contra apenas 10\% em 2000. Em contraponto, o número de residências com rádio caiu de $87 \%$ em 2000 para $81 \%$ em 2010.

8Disponível em: <http://www.observatoriodaimprensa.com.br/news/view/comuniquese_37764>. Acesso em: 10 jul. 2013. 
Gráfico 1- Frequência de residências com TV, Rádio e Computador em Campos dos Goytacazes em 2000 e 2010

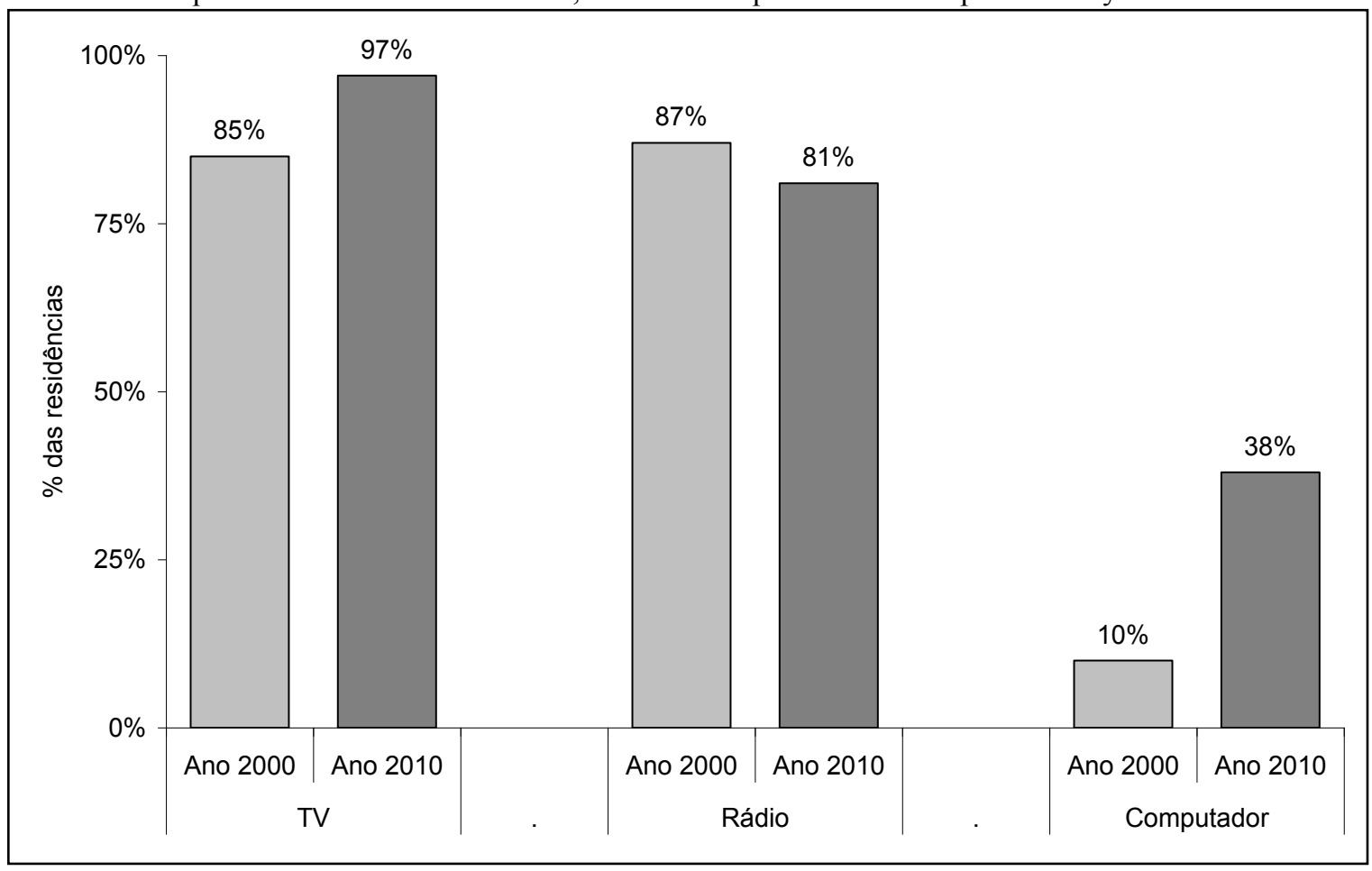

Fonte: Censo IBGE 2000/2010

Fazendo uma análise mais detalhada em relação à ferramenta necessária para a população ter acesso às informações públicas do Município, podemos observar no Gráfico 2 que, em 2010, $62 \%$ das pessoas ainda não tinham sequer o computador em suas residências. E das $38 \%$ das residências que tinham computador no Censo de 2010 , o percentual de $30 \%$ tinha acesso à internet enquanto $8 \%$ não possuíam este acesso. Isso significa que no ano de 2010 apenas $30 \%$ teriam condições de buscar, da própria residência, informações de interesse público no site oficial da Prefeitura.

Gráfico 2- Frequência de residências com computador e acesso à Internet em Campos dos Goytacazes em 2010

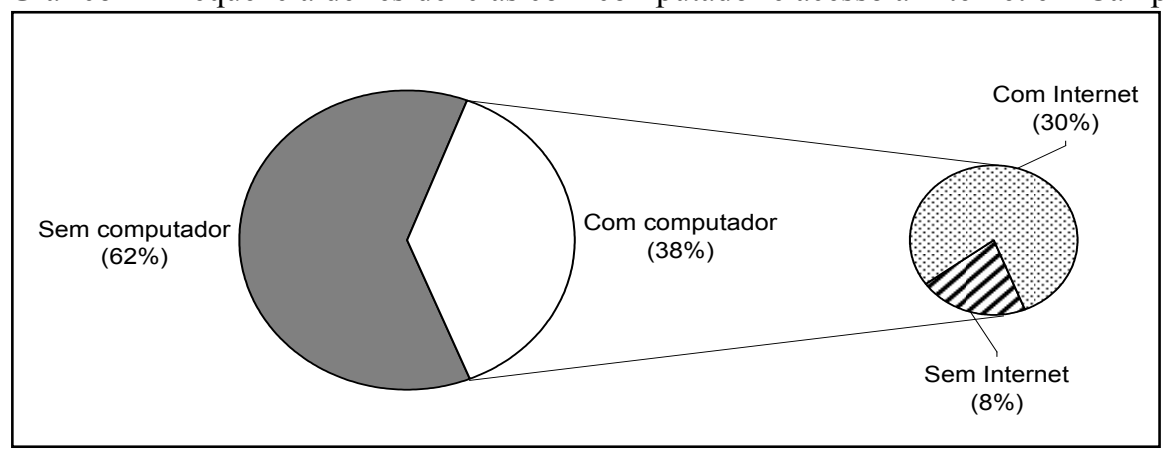

Fonte: Elaboração própria a partir do Censo 2010

Outro documento que trata da informação e comunicação no Município é o Plano

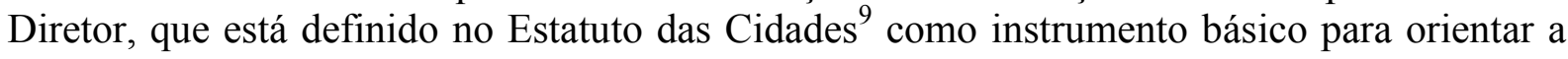

\footnotetext{
${ }^{9}$ A Lei Federal 10.257/2001, mais conhecida como Estatuto das Cidades, é a regulamentação dos artigos 182 e 183 da Constituição Federal e estabelece parâmetros e diretrizes da política e gestão urbana no Brasil.
} 
política de desenvolvimento e ordenamento da expansão urbana. Trata-se de uma lei municipal elaborada pelo executivo com a participação da Câmara dos Vereadores e da sociedade civil, com o objetivo de orientar as ações do poder público visando compatibilizar os interesses coletivos e garantir de forma mais justa os benefícios da urbanização, garantir os princípios da reforma urbana, direito à cidade e cidadania, gestão democrática da cidade.

O Plano Diretor do Município de Campos dos Goytacazes prevê estratégias para promover a participação da sociedade na formulação e implementação das políticas públicas, garantindo o pleno exercício da cidadania, como fortalecimento dos Conselhos, realização de debates, consultas e audiências públicas.

Lira (2012), na tese de Doutorado, discute a Representação, Participação e Cooptação nos Conselhos Municipais em Campos dos Goytacazes. O objetivo do estudo foi analisar os processos políticos locais com foco nos Conselhos Municipais, visando identificar características da qualidade da participação e representação da sociedade nestes organismos.

$\mathrm{Na}$ análise do autor, os Conselhos Municipais podem ser vistos como mecanismo de participação e agentes de accountability ao se apresentarem como canais de vocalização da sociedade civil participando nas instâncias de formulação de políticas públicas locais e de acompanhamento do desempenho do governo.

Os Conselhos Municipais surgem com o objetivo de serem canais de participação, com o fim de propiciar um novo padrão de relações entre o Estado e a sociedade ao viabilizarem a presença de diferentes segmentos sociais na elaboração da agenda e na formulação das políticas públicas (LIRA, 2012, p. 41).

O autor conclui que:

[...] as pesquisas indicaram no caso de Campos, fragilidade dos Conselhos Municipais em garantir a responsividade dos dirigentes em relação às demandas da sociedade. No entanto, em que pese esta fragilidade em algumas áreas das políticas públicas os Conselhos fortaleceram o controle social (LIRA 2012, p. 107).

Em relação à Informação e Comunicação, o Plano Diretor prevê a implementação de diretrizes relativas à disseminação das informações e ampliação dos meios de comunicação, por meio da atualização permanente da base de dados sobre o Município e sua divulgação à população, criação de serviço de utilidade pública no site da Prefeitura como emissão de certidões e outros documentos de interesse do cidadão.

O Município possui também no site oficial, o Portal da Transparência. A página inicial, conforme ilustra a Figura 2, indica que o portal coloca à disposição do cidadão dados sobre a administração, com informações sobre arrecadação e despesas, entre outras. À época da pesquisa (setembro de 2013) o texto colocado na página inicial estava inalterado desde o ano de 2009, apesar de conter no site a informação de que este é um canal de prestação de contas à sociedade através da internet, em permanente construção e atualização. 
Figura 2 - Página inicial do Portal da Transparência.

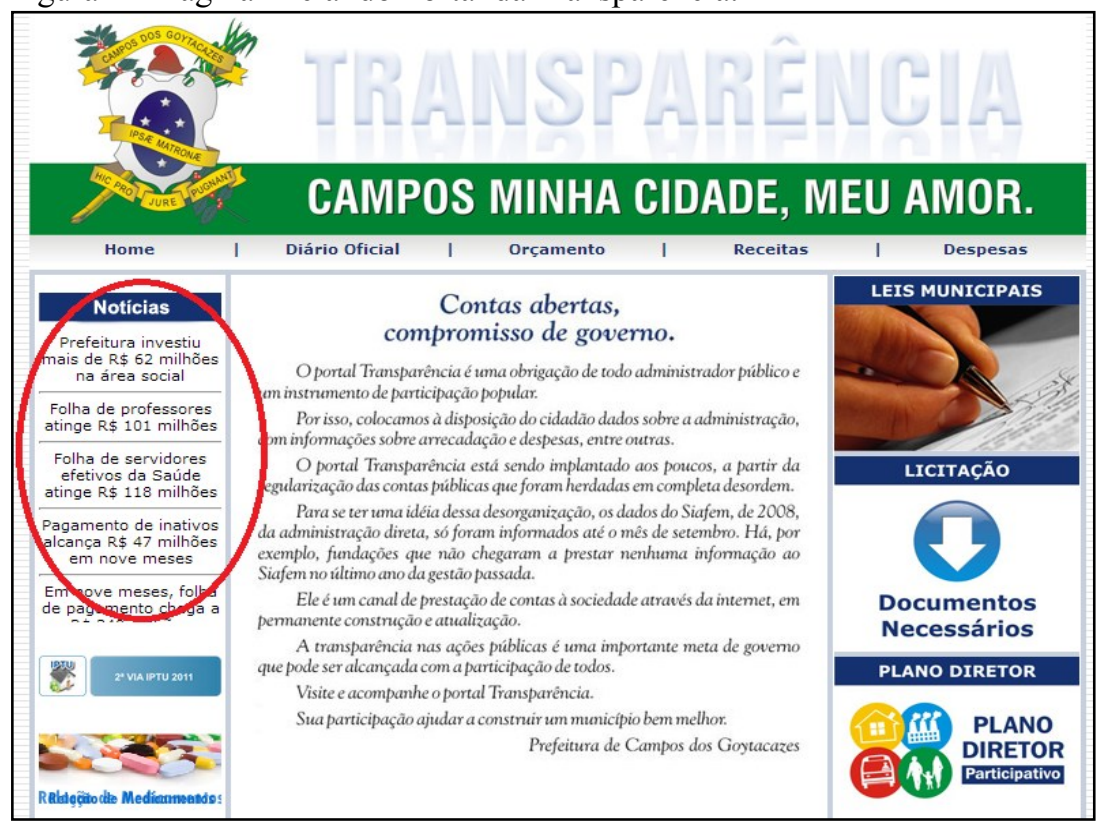

Fonte: Campos dos Goytacazes. Prefeitura Municipal (2013).

Diante do exposto, o objetivo principal desta pesquisa é, a partir da análise de conteúdo do site e das informações veiculadas através de notícias, revelar se há disparidades e/ou tensões existentes entre os instrumentos que garantem o acesso à informação e as práticas exercidas pela Prefeitura de Campos dos Goytacazes.

\section{O PERCURSO DA PESQUISA E A INVESTIGAÇÃO}

Essa seção apresenta os caminhos trilhados no trabalho de campo sob à luz dos referenciais teóricos adotados e dos procedimentos metodológicos utilizados. A coleta de dados foi realizada em duas etapas. A primeira compreendeu na aplicação de questionário ao Secretário de Comunicação do Município. A segunda primou pela análise de conteúdo, com a categorização das informações veiculadas, apenas em forma de notícia, no site oficial da prefeitura. Para essa etapa, foram analisadas e categorizadas um universo de 2.535 (duas mil quinhentas e trinta e cinco notícias) publicadas no período de janeiro a junho de 2013.

O procedimento para a coleta de dados na Secretaria de Comunicação Social teve início no dia 05 de fevereiro de 2013, quando foi realizado um primeiro contato telefônico com uma jornalista do quadro, nesse contato foi solicitado um agendamento de entrevista com o secretário da pasta, o jornalista Sérgio Augusto dos Santos Cunha. A jornalista requisitou que fosse enviado, via e-mail, um roteiro da entrevista para que o secretário pudesse "adiantar" algumas respostas que necessitasse de buscas e pesquisas no setor, já que o mesmo contava com uma agenda apertada de compromissos. A solicitação foi atendida e o questionário foi enviado no mesmo dia para a jornalista. $\mathrm{O}$ objetivo era coletar informações sobre o funcionamento da Secretaria de Comunicação, as atribuições do setor, as formas e ferramentas de trabalho. 
Um mês depois, no dia 05 de março, após várias tentativas de contato telefônico e mensagens através de redes sociais com alguns jornalistas que atuam na secretaria, foi enviado o questionário para outra jornalista que havia se colocado a ajudar, fornecendo inclusive número de telefone celular do secretário para agendar a entrevista. Em contato telefônico com o Secretário de Comunicação, o mesmo me solicitou que fizéssemos contato com sua assessora para que a entrevista fosse marcada. A assessora também nos solicitou que enviasse o questionário para o e-mail dela e disse que faria contato para marcar a data da entrevista. Após sete meses de espera, idas à Secretaria, contatos telefônicos, e-mails e mensagens em redes sociais, o Secretário de Comunicação, Sérgio Augusto dos Santos Cunha, encaminhou o questionário respondido, no dia 22 de setembro de 2013, sete meses após o primeiro contato. O secretário informou ainda, que estava deixando o cargo e que em seu lugar assumiria Mauro Silva, que era o Secretário de Comunicação antes dele, e que havia saído para se colocar como candidato a vereador nas eleições de 2012, sendo inclusive eleito.

Com apenas este relato, podemos perceber a fragilidade da Prefeitura de Campos em fornecer informações de interesse público a um cidadão. E para maior surpresa, após sete meses aguardando o retorno do questionário, o recebemos com respostas monossilábicas, sem aprofundamento ou preocupação na busca de uma informação mais completa, como será visto na seção seguinte.

\section{CARACTERÍSTICAS DO UNIVERSO DA PESQUISA: CONHECENDO A SECRETARIA DE COMUNICAÇÃO SOCIAL DA PREFEITURA DE CAMPOS DOS GOYTACAZES}

Nessa seção fizemos uma breve apresentação do órgão responsável pela Comunicação no Município, a Secretaria de Comunicação Social (Secom), assim como também apresentamos a análise feita a partir do levantamento das notícias publicadas no site do referido órgão.

A Secom passou por uma reestruturação, após a Lei $\mathrm{N}^{0}$ 8.344, de 13 de maio de $2013^{10}$, essa lei instituiu a estrutura administrativa básica da Prefeitura Municipal de Campos dos Goytacazes, criou e modificou cargos de provimento em comissão e função gratificada, dando outras providências. De acordo com a lei, no Art. 11, a Secretaria Municipal de Comunicação tem as seguintes atribuições e competências:

\footnotetext{
I - planejar, executar e orientar a política de comunicação social da Prefeitura Municipal de Campos dos Goytacazes, objetivando a uniformização dos conceitos e procedimentos de comunicação;

II - executar as atividades de comunicação social do Gabinete do Prefeito;

III - coordenar a contratação dos serviços terceirizados de pesquisas, assessoria de imprensa, publicidade e propaganda da Administração Municipal;

IV - coordenar as atividades de comunicação social dos órgãos e entidades públicas da Prefeitura Municipal de Campos dos Goytacazes, centralizando a orientação das assessorias de imprensa dos órgãos e entidades públicas da Administração Municipal;

V - promover a divulgação de atos e atividades do Governo Municipal;
}

\footnotetext{
${ }^{10}$ A lei foi publicada na p. 2 do Diário Oficial do Município, a. 5, n. 39, Campos dos Goytacazes, do dia 28 de maio de 2013.
}

DRd - Desenvolvimento Regional em debate (ISSNe 2237-9029) 
VI - promover, através de órgãos públicos, associações, imprensa, agências e outros meios, a divulgação de projetos de interesse do Município;

VII - coordenar e facilitar o relacionamento da imprensa com o Prefeito, os Secretários Municipais e demais autoridades da Administração do Município;

VIII - manter arquivo de notícias e comentários da imprensa do Estado sobre as atividades da Administração Municipal, para fins de consulta e estudo;

IX - coordenar, juntamente com os demais órgãos do Município, as informações e dados, cuja divulgação seja do interesse da Administração Municipal;

X - coordenar a divulgação de notícias sobre a Administração Municipal na internet, através do portal oficial da Prefeitura Municipal de Campos dos Goytacazes;

XI - coordenar a uniformização dos conceitos e padrões visuais com a aplicação dos símbolos municipais da Prefeitura Municipal e todas as Secretarias e órgãos vinculados;

XII - proceder, no âmbito do seu órgão, à gestão e ao controle financeiro dos recursos orçamentários previstos na sua unidade, bem como à gestão de pessoas e recursos materiais existentes, em consonância com as diretrizes e regulamentos emanados do Chefe do Poder Executivo;

XIII - exercer outras atividades correlatas. (D.O.M, Lei No 8.344, a. 5, n. 39, 13 de maio de 2013)

O anexo II da referida lei, que trata da relação de cargos em comissões e funções gratificadas por órgão, estabeleceu os cargos e funções gratificadas para a Secom, conforme mostra o Quadro 1.

Quadro 1 - Cargos e funções gratificadas da Secretaria Municipal de Comunicação

\begin{tabular}{|l|c|}
\hline \multicolumn{1}{|c|}{ Cargos } & Funções Gratificadas - DAS \\
\hline Secretário de comunicação & DAS-1 \\
\hline Assessor de comunicação gab. Prefeita & DAS-2 \\
\hline Subsecretário & DAS-2 \\
\hline Chefe de gabinete & DAS-3 \\
\hline Diretor de relações públicas & DAS-3 \\
\hline Diretor de mídia & DAS-3 \\
\hline Diretor adm. financeiro & DAS-3 \\
\hline Diretor de jornalismo & DAS-3 \\
\hline Diretor de comunicação interna & DAS-3 \\
\hline Diretor de publicidade e propaganda & DAS-3 \\
\hline Diretor de eventos e redes sociais & DAS-3 \\
\hline Assessor jurídico & DAS-3 \\
\hline Diretor de comunicação smfas & DAS-4 \\
\hline Diretor de comunicação fms & DAS-4 \\
\hline Assessor especial & DAS-4 \\
\hline Assessor especial & DAS-4 \\
\hline Assessor especial & DAS-4 \\
\hline Assessor especial & DAS-4 \\
\hline Assistente de imprensa & DAS-6 \\
\hline Chefe de divisão áudio visual & DAS-7 \\
\hline Chefe de divisão de fotografia & DAS-7 \\
\hline Chefe de jornalismo & DAS-7 \\
\hline Chefe de divisão de projetos especiais & DAS-7 \\
\hline Chefe de divisão de sonorização & DAS-7 \\
\hline Chefe de divisão de tec. da informação & DAS-7 \\
\hline Chefe de divisão de assuntos corporativos & DAS-7 \\
\hline Chefe de divisão de locução & DAS-7 \\
\hline Chefe de divisão de mkt e art. Gráficas & DAS-7 \\
\hline Font Le 8.344, 13 má & \\
\hline
\end{tabular}

Fonte: Lei $\mathrm{N}^{\mathrm{o}} 8.344$, de 13 de maio de 2013.

DRd - Desenvolvimento Regional em debate (ISSNe 2237-9029) 
O Quadro 1 mostra que somente na Secom, 28 pessoas ocupam cargos com funções gratificadas. O objetivo inicial desta metodologia era de analisar a Secom, através do conteúdo da Reforma Administrativa publicada no Diário Oficial, e por meio de uma entrevista semi-estruturada com o Secretário Municipal de Comunicação. Como não houve sucesso com o objetivo pretendido, primou-se pela aplicação de questionário, no qual o Secretário respondeu as questões.

O Secretário de Municipal de Comunicação, Sérgio Augusto dos Santos Cunha, tem 41 anos, vinte anos de experiência profissional, tendo atuado nos jornais A Cidade, Folha da Manhã e Folha de São Paulo, como correspondente, além de ter atuado na assessoria de comunicação de um deputado federal. O Secretário informou ser servidor público, tendo exercido na Secom as funções de Diretor de Jornalismo, Subsecretário e Secretário, por um período de 18 meses.

Em relação à estrutura organizacional, o secretário respondeu que são cerca de 40 servidores, entre jornalistas, estagiários, designers, radialistas, locutores, assistentes administrativos, além de pessoal de apoio como motoristas, secretária e limpeza. Informou ainda que a Secom tem setores que cuidam da mídia impressa, produção de conteúdo, assessoria de imprensa, relacionamento com veículos (TV, rádio, jornal, portais de notícias), propaganda e marketing, produção de materiais de divulgação de perfil interno e externo, locução para rádio, das redes sociais e do site oficial da Prefeitura.

Sobre o dimensionamento da força de trabalho, o Secretário respondeu que a Secom atua no desenvolvimento, coordenação e implementação da estratégia de comunicação de toda administração municipal, envolvendo as secretarias, as autarquias e empresas públicas, e busca fazer com que a força de trabalho disponibilizada acompanhe a evolução do desafio de gestão proposto.

Perguntado se o Município possuía políticas de comunicação que norteiam as atividades da Secom, o Secretário respondeu que: "Sim, a Secretaria de Comunicação desenvolve uma política de interação com a comunidade, através de redes sociais e programas de rádios, além de desenvolver a comunicação integrada com todos os veículos de comunicação da cidade". Ele informou ainda que as notícias publicadas no site da Prefeitura são categorizadas no âmbito da Comunicação Pública, além de trabalhar também no âmbito da Comunicação Governamental.

Em relação aos atuais volumes de recursos investidos em comunicação em Campos dos Goyatacazes, o Secretário apenas informou que "os investimentos em comunicação respeitam uma margem inferior a $2 \%$ do orçamento anual do Município, enquanto cidades de médio porte e capitais praticam uma média de 5\% a 15\%". Sobre o fato dos gastos em comunicação no Município não aparecerem de forma clara no Portal da Transparência, o Secretário informou que "todas as despesas do município estão relacionadas no Portal da Transparência através de pagamento a empresas contratadas e prestadores de serviços diversos".

Perguntado se a Secom faz parte de algum conselho municipal, informou que embora a Secom não seja membro efetivo de nenhum conselho municipal, está presente na maioria deles, acompanhando as discussões plenárias para posterior discussão de casos e atuando na divulgação das ações que surgem nas reuniões dos conselhos. E sobre a avaliação que o 
Secretário fazia da articulação da Secretaria de Comunicação Social com os conselhos municipais, foi respondido que era positiva e proveitosa, levando-se em consideração que, na medida em que a Secom está presente nas reuniões, mesmo não sendo membro efetivo, posteriormente pontos levantados pelos conselheiros são transformados em estudo de casos, como forma de ajudar na participação de soluções.

Em relação aos espaços de diálogo e participação que a Prefeitura mantém com a população, o Secretário descreveu "redes sociais (Facebook e Twiter) e, também, rádio, televisão, jornal e ouvidoria”.

Perguntado se tinha conhecimento da Lei Orgânica do Município, no seu artigo 94, que prevê que a publicação das leis e atos municipais será feita no Diário Oficial do Município, e, na falta deste, em órgão da imprensa local, que na lei está previsto que a escolha do órgão de imprensa para divulgação das leis e atos administrativos far-se-á através de licitação, em que se levarão em conta não só as condições de preços, como as circunstâncias de frequência, horário, tiragem e distribuição, respondeu que o Diário Oficial é disponibilizado de forma impressa, com publicação definida por Licitação Pública, conforme orientação e aprovação dos órgãos de fiscalização, além de ser oferecido de forma eletrônica. Atualmente, o Diário Oficial do Município está no portal oficial da Prefeitura $<$ www.campos.rj.gov.br>. E complementou, quando questionado se toda a população tinha acesso ao Diário Oficial, respondendo que: "Sim, além de estar hospedado no site oficial da Prefeitura na internet em sua integridade com edições regulares, todas as secretarias municipais dispõem de exemplares. E, ainda, pode ser encontrado em bancas de jornal da cidade".

As perguntas que constavam no questionário sobre a ouvidoria do Município e sobre a LAI, inclusive se tinha ao menos conhecimento da referida lei, o Secretário não respondeu, informando apenas que "os itens são indagações que não se referem à minha área de atuação".

Diante do exposto, fazemos as seguintes reflexões: as respostas rasas acima relacionadas, enviada pelo Secretário Municipal de Comunicação, não são coerentes com os sete meses de espera. No item em que o Secretário descreve a estrutura organizacional, notase uma discrepância entre o número de cargos com funções gratificadas $(28$ - todos preenchidos) e o número de funcionários (40), incluindo os motoristas e pessoal de apoio. Quando perguntado sobre as políticas de comunicação, o Secretário descreve ferramentas, como as redes sociais e a rádio, demonstrando um desconhecimento sobre o tema. Também não ficou claro em que âmbito são discutidas as políticas de comunicação, já que ele afirma que a pasta não é membro efetivo de nenhum conselho, que atua apenas na divulgação das decisões. Em relação aos recursos destinados para a Secom, o Secretário limita-se a fazer uma comparação com outros municípios. Além disso, as informações disponibilizadas no Portal da Transparência, não especificam os tipos de serviços realizados. E, por fim, ele não respondeu a pergunta se tinha conhecimento da LAI. Mesmo que não fosse de sua área de atuação, como colocado, seria razoável ter conhecimento da mesma, já que atua diretamente com informação. 


\section{A ANÁLISE DE CONTEÚDO: CATEGORIA DAS INFORMAÇÕES VEICULADAS PELAS NOTÍCIAS}

Esta pesquisa adotou a Análise de Conteúdo das informações veiculadas no site oficial da Prefeitura, apenas em forma de notícia. Foram analisadas 2.535 (duas mil quinhentas e trinta e cinco) notícias publicadas no período de janeiro a junho de 2013. A maioria das notícias publicadas pautou as redações de rádios, jornais e TVs do Município e seu entorno, o que leva a crer que estas informações, as veiculadas em forma de notícias, possuem um alcance maior da população e são as principais fontes de informação que a população possui junto ao governo.

De acordo com Bardin (2011), a categorização é uma operação de classificação de elementos constitutivos de um conjunto por diferenciação e, em seguida, por reagrupamento com os critérios previamente definidos. "A categorização tem como primeiro objetivo fornecer, por condensação, uma representação simplificada dos dados brutos" (BARDIN, 2011, p. 159).

Para a classificação das notícias, foram criadas cinco categorias baseadas nos instrumentos da Comunicação Pública definidos por Duarte (2009). As notícias foram didaticamente agrupadas nas seguintes categorias:

1 - Ações da Gestão - relativos ao processo decisório e de ação dos agentes que atuam em temas de interesse público. Incluem discursos, metas, intenções, motivações, prioridades e objetivos dos agentes para esclarecer, orientar e municiar o debate público. "O cidadão e os diferentes atores precisam saber o que está acontecendo em temas relacionados a acordos, ações políticas, prioridades, debates, execução de ações" (DUARTE 2009, p. 62);

2 - Dados Públicos: “[...] referente às informações de controle do Estado e que dizem respeito ao conjunto da sociedade e a seu funcionamento" (DUARTE, 2009, p. 62). Exemplos: normas legais, estatísticas/balanços, decisões judiciais, documentos históricos e legislação;

3 - Eventos: são registradas matérias relacionadas a ofertas da prefeitura com essa temática, divulgação de eventos dos quais a prefeitura participa ou organiza. $\mathrm{O}$ importante nesta categoria foi identificar matérias que se apresentam com o registro de atividades, são factuais e não apresentam qualquer outra espécie de complemento, contextualização ou aprofundamento.

4 - Prestação de contas: "[...] dizem respeito à explicação e esclarecimento sobre decisões políticas e uso de recursos" (DUARTE, 2009, p. 62). Viabiliza o conhecimento, avaliação e fiscalização por parte da população diante da ação de um governo;

5 - Utilidade Pública - encaixam-se as matérias sobre temas relacionados ao dia a dia das pessoas, geralmente serviços e orientações. "[...] Imposto de renda, campanhas de vacinação, questões de ordem urbana como sinalização, causas sociais, informações sobre serviços à disposição e seu uso são exemplos típicos” (DUARTE 2009, p. 62). 
No preparo das informações, o trabalho realizado se voltou inicialmente à leitura/releitura apenas dos títulos das matérias selecionadas com algumas anotações pertinentes das mesmas. A partir disso, foram selecionadas as temáticas que emergiram, ou seja, aquelas que apenas pelo título já poderiam ser inicialmente agrupadas transformando tais temáticas em unidades de análise. Em seguida, realizamos a categorização no agrupamento das notícias nas principais categorias estabelecidas. Em um momento posterior, foram selecionadas as notícias que, por falta de clareza, não puderam ser classificadas apenas pelo título. Então essas notícias (416) só puderam ser categorizadas após leitura detalhada de todo o conteúdo.

A categorização é uma etapa fundamental no processo de pesquisa. Para que esta fase se efetive com eficácia, há a necessidade de se obedecer a alguns critérios: de pertinência (de acordo com os objetivos da pesquisa); exaustividade (todos os dados devem ser vistos e os que são significativos, incluídos); homogeneidade (para que nenhuma questão seja tratada com particularidade); exclusividade (em que cada elemento deve estar vinculado a apenas uma categoria) e, por fim, deve obedecer ao critério de fidedignidade (se volta à objetividade da pesquisa, consistência das categorias e relevância científica) (MORAES, 1999; ROCHA; DEUSDARÁ, 2005).

Do universo das 2.535 notícias, a categoria Ações da Gestão agrupou 744 notícias, correspondendo a $29,3 \%$ do universo, enquanto 1.200 foram categorizadas em Eventos, um número bastante expressivo, correspondendo a $47,3 \%$ do total das notícias publicadas neste período. Essas duas primeiras categorias juntas correspondem a 76,6\% do total, já sinalizando que a prioridade são conteúdos que promovam o gestor público e seus feitos, revelando o esforço para aliar as pautas mais constantes à imagem do governante.

A categoria Dados Públicos correspondeu a apenas 1,4\%, em números absolutos totalizam 36 notícias. Com relação à categoria Prestação de Contas, observa-se que apenas $3,4 \%$ (85) das notícias classificadas possuem informações com essa temática, o que demonstra uma falta de preocupação dos dirigentes públicos em informar ao cidadão, pelo menos, por meio das notícias, como está sendo gasto o dinheiro público, como e onde está sendo aplicado. Em Utilidade Pública foram classificadas 470 notícias, 18,5\%. Esse tipo de notícia instrui o cidadão a utilizar melhor os serviços públicos e o orienta de forma consistente, rápida e adaptada às suas necessidades. 
Gráfico 3- Categorização geral das informações em forma de notícias.

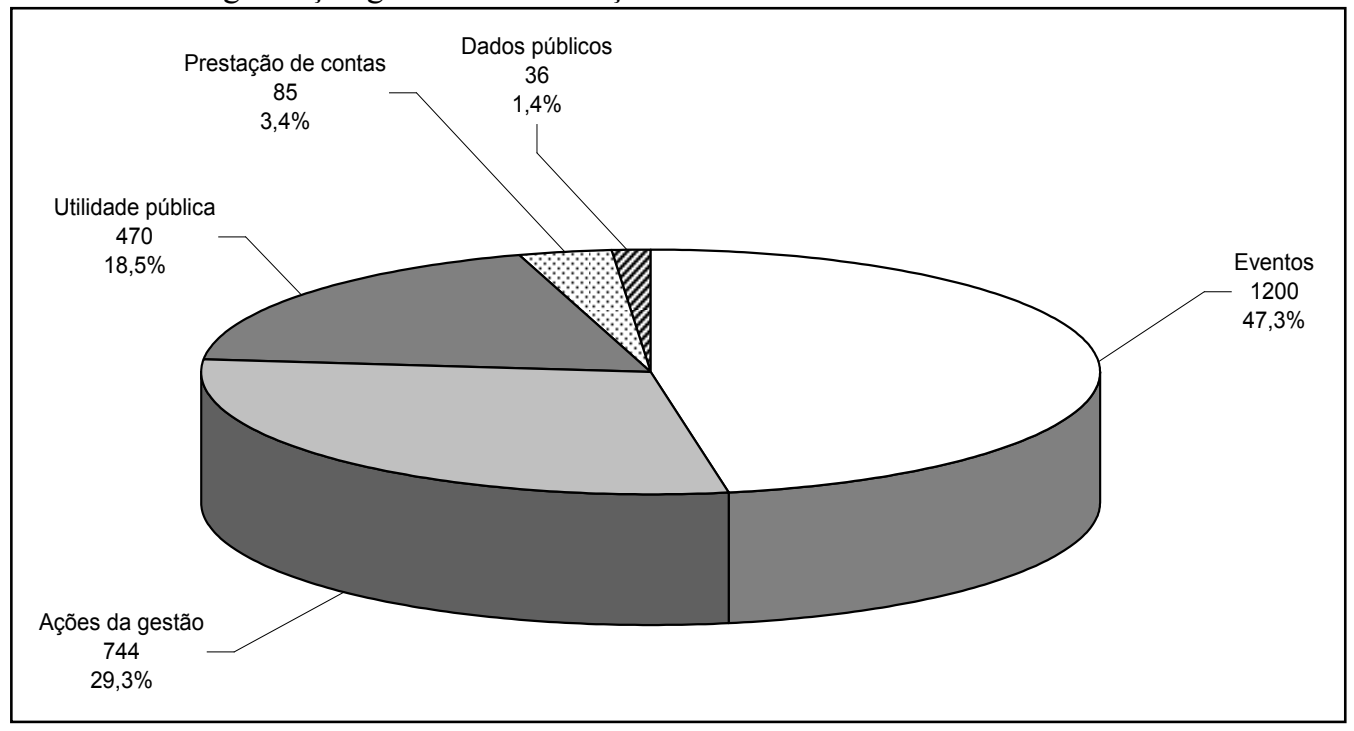

Fonte: elaboração própria

Após a categorização geral das notícias, as mesmas foram reagrupadas em temáticas que emergiram durante a análise. São elas:

1) Eventos: shows, esporte, teatro, cinema, desfiles, oficinas, feiras, festivais/festas, palestras e semelhantes, exposições, carnaval, programação, aniversários/homenagens e outros;

2) Ações da Gestão: obras/inaugurações, campanhas de conscientização/ações, reuniões, royalties, agenda prefeita, projetos/programas e outros;

3) Utilidade Pública: balcão de empregos, questões urbanas, royalties, inscrições, convocações/recadastramentos, calendário de vacinação, servidores, PROCON, hemocentro, cursos e outros;

4) Prestação de Contas: audiências, câmara, conselhos;

5) Dados Públicos: legislação/normas, estatísticas/balanços e publicações.

Ao adentrar na categoria Eventos, podemos observar no Gráfico 4 que se trata de um conteúdo em que a Prefeitura dispensa maior atenção e prioridade. São 1.200 notícias, correspondentes a 47,3\% do total classificado. Os agrupamentos feitos nesta categoria não diferenciam muito o teor da informação, apenas setoriza os tipos de eventos promovidos e divulgados pela Prefeitura. Os shows estão presentes em todos os meses analisados, apesar de estarem um pouco mais concentrados nos meses de janeiro e fevereiro, quando a praia campista do Farol de São Thomé concentra uma vasta programação. Principalmente, nesta categoria, as notícias não trazem qualquer informação que demonstre clareza e transparência na forma que os eventos foram organizados, pagos e por quem executados. São notícias factuais com dia, horário e local, em sua grande maioria. 
Gráfico 4- Categorização das informações sobre Eventos

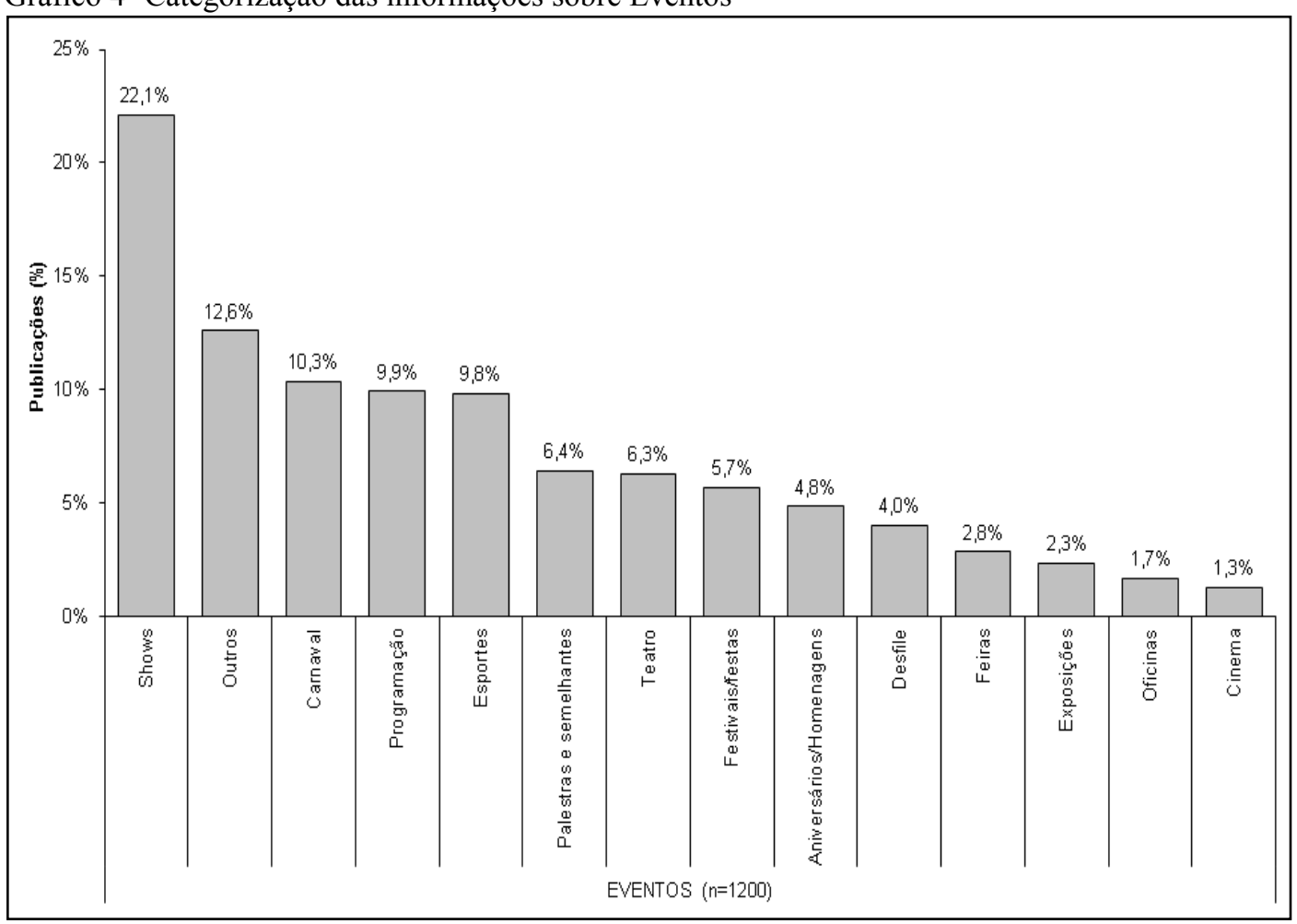

Fonte: Elaboração própria

Sobre a categoria Ações da Gestão podemos observar no Gráfico 5 que a ação prioritária do governo, ou pelo menos a mais divulgada, são as obras e inaugurações, com $26,7 \%$ do total deste grupo. 
Gráfico 5 - Categorização das informações sobre Ações da Gestão

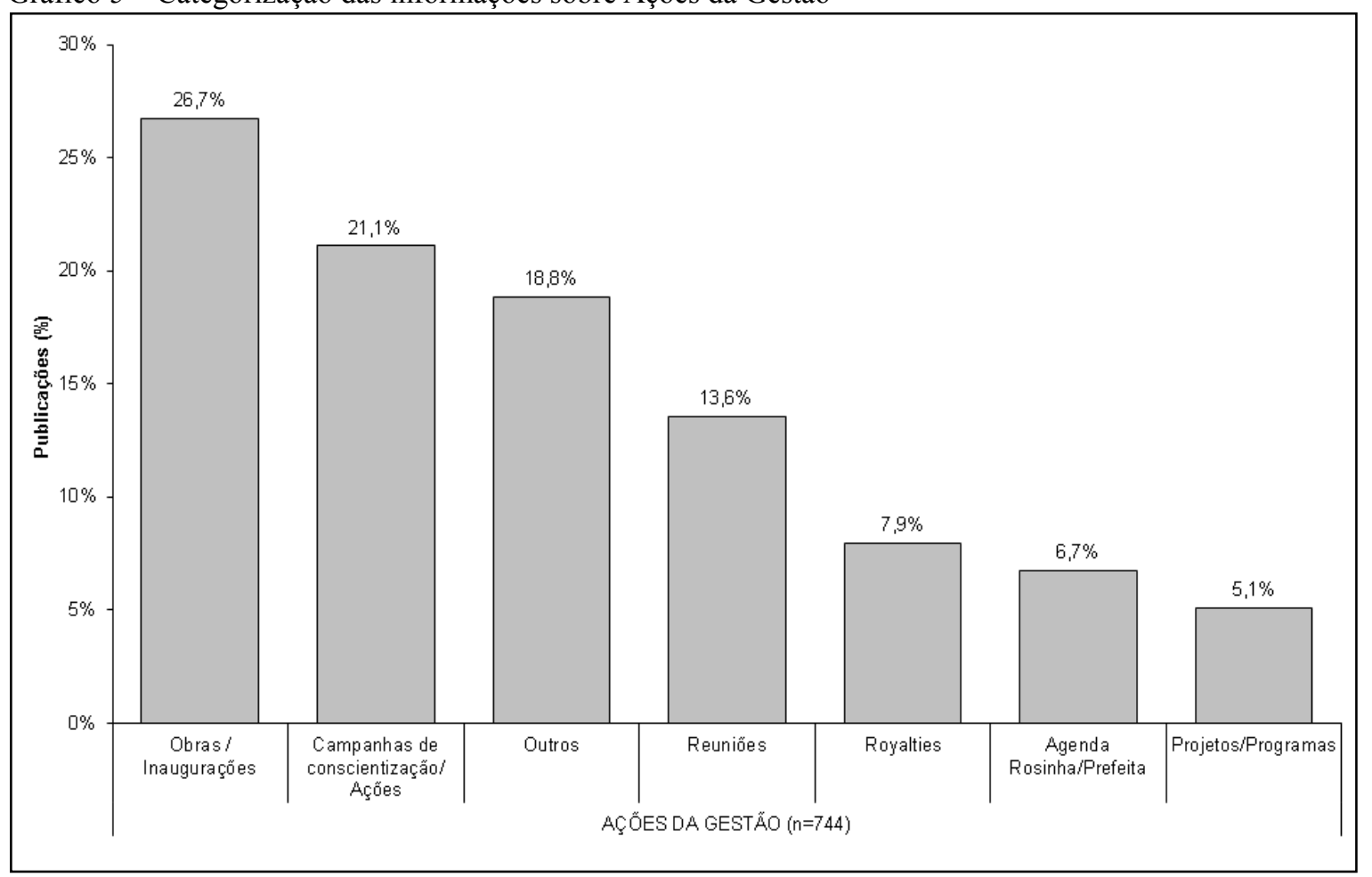

Fonte: Elaboração própria

As notícias classificadas em Obras/Inaugurações são relativas às reformas de praças, escolas, creches, Bairro Legal (asfaltamento, sinalização, drenagem, entre outros), Morar Feliz (conjunto habitacional) e inauguração das mesmas. Outra análise em relação à categoria é o fato das notícias informarem que está sendo construído, que será entregue, datas, prazos, mas não cita valores gastos, de que forma foram licitadas, ou seja, trata-se de notícias com conteúdos superficiais, sem informações que demonstrem transparência por parte do governo, apesar dos valores vultosos que devem ser destinados para este fim.

Em Campanhas de Conscientização/Ações, que somam 21,1\% do total, estão notícias sobre combate à dengue, conscientização no trânsito, mutirões, ações da vigilância sanitária, campanhas contra a pedofilia, entre outras ações, apesar de serem informações de utilidade pública, as notícias em si se encarregam apenas de promover o gestor que participou do ato.

O item Reuniões $(13,6 \%)$ agrupou todas as notícias que, em seu teor, informavam apenas sobre a participação de dirigentes do governo em reuniões, de forma pontual e factual, sem qualquer outro aprofundamento.

As notícias sobre Royalties, classificadas dentre das Ações da Gestão, somam apenas $7,9 \%$ e apresentam no mínimo três fatos que merecem análise. Primeiro, todas foram publicadas entre os dias 05 e 25 de março do decorrente ano. Segundo, todas versam sobre o ato público intitulado Em Defesa dos Royalties e da Constituição, organizado pela Prefeitura em 07 de março, dia em que o Congresso Nacional derrubou os vetos da Presidente Dilma Rousseff à Lei $\mathrm{N}^{\circ} 12.734 / 12$, que redistribui os royalties do pré-sal. E terceiro, as notícias se resumem em informar ao cidadão apenas sobre o evento "ato", com dia, horário, local e quem 
participaria, mas não explica detalhadamente o teor da referida lei. Algumas insinuam apenas que sem royalties muitos estarão desempregados ou sem atendimento médico, por exemplo.

Em Agenda Prefeita (6,7\%) estão listadas viagens, encontros, participações, lançamentos e inaugurações em que a Prefeita se fez presente. Também em sua maioria, são notícias factuais e sem aprofundamento.

O item Projetos/Programas foram agrupadas notícias sobre combate às drogas, controle de tabagismo, Guarda Mirim, DST/Aids, entre outros. Nota-se nessa categoria que, apesar de ser de interesse da população ter conhecimento dos programas e projetos desenvolvidos, este tipo de ação, totalizada com $5,1 \%$, não é ponto de pauta relevante para o governo. As notícias colocadas em Outros, que somam 18,8\%, possuem temas variados de ações aleatórias como "Secretaria se aproxima cada vez mais da população", "Grupamento Ambiental identifica coruja no Heliporto" e "Fiscais da EMUT estão nas ruas para combater irregularidades". São notícias com temáticas isoladas, únicas e atípicas.

A categoria Utilidade Pública, reúne informações relacionadas ao dia a dia do cidadão. O agrupamento desta categoria, conforme Gráfico 6, reúne serviços à disposição e seu uso, além de orientações.

Gráfico 6 - Categorização das notícias em Utilidade Pública.

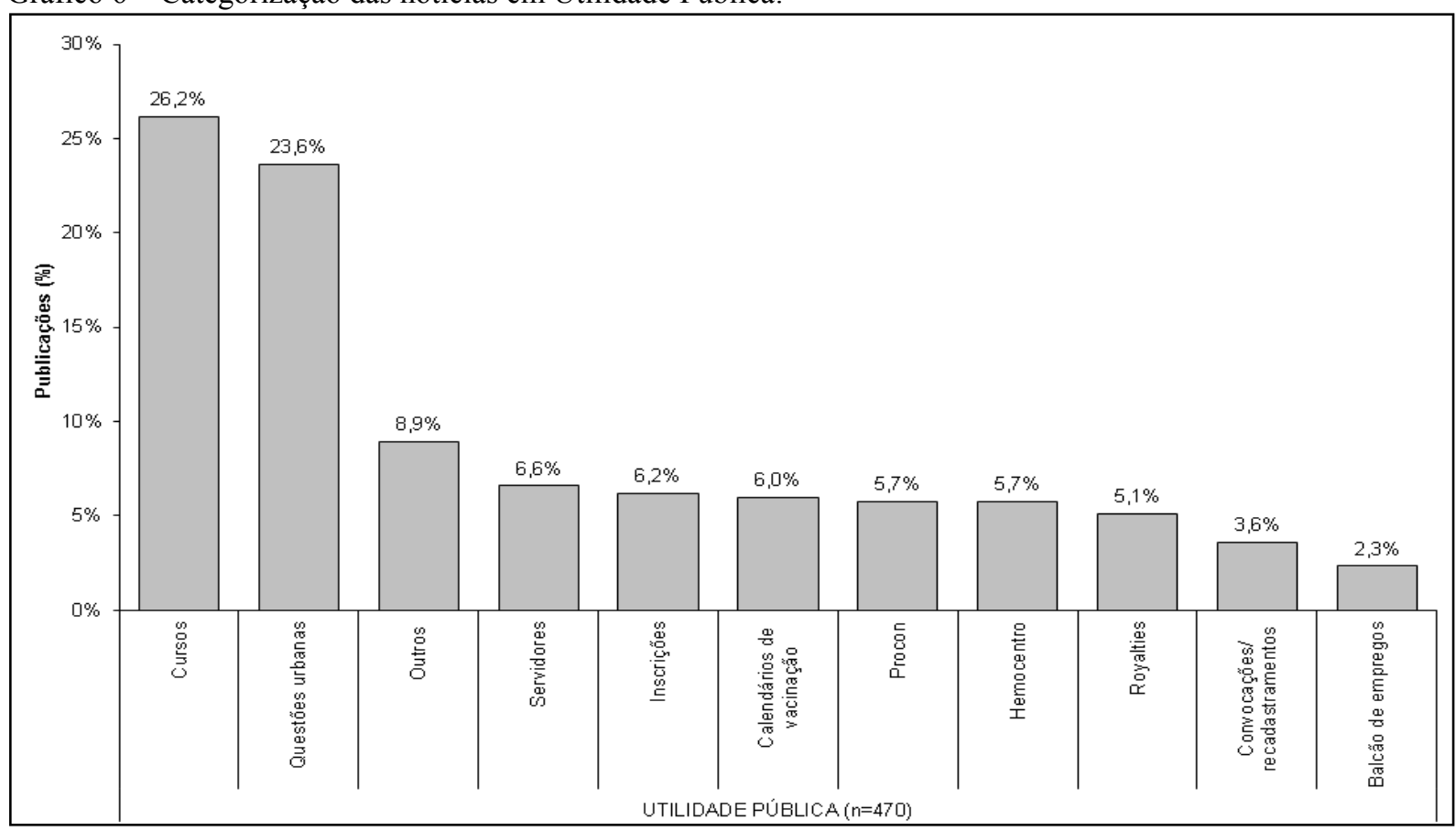

Fonte: Elaboração própria

As informações agrupadas em Questões Urbanas estão relacionadas às orientações sobre transporte coletivo, trechos interditados, mobilidade, ações da Defesa Civil em decorrência, por exemplo, de chuvas e alagamentos, fornecimento de água e coleta de lixo. 
Observa-se que esse tipo de notícia não deixa de ser uma ação da gestão, mas são ações que interferem diretamente no dia a dia do cidadão, portanto, é fundamental que seja de seu conhecimento.

Os agrupamentos Cursos, Inscrições, Convocações/recadastramentos, Balcão de Empregos e Campanhas de Vacinação têm a mesma temática de ofertas para a população, com informações sobre prazos, datas, locais de comparecimento e encaminhamentos. $\mathrm{O}$ item PROCON e Hemocentro reúnem uma série de orientações aos usuários, neste caso, o cidadão. Em Servidores foram classificadas as notícias específicas deste público. Trata-se de datas de pagamentos, informações sobre previdência, reajuste salarial, FGTS, entre outros.

Já analisado na categoria Ações da Gestão, o item Royalties figura também em Utilidade Pública. Observa-se que o conteúdo das notícias aqui analisadas informa o cidadão sobre decisões políticas como concessão de liminares, as consequências em decorrência da nova lei, além de depoimentos de representantes da sociedade civil em relação à mobilização.

Em Outros estão agrupadas informações sobre IPTU, horário de funcionamento de uma determinada unidade de saúde, cheque cidadão, informações turísticas, mudanças de endereços, entre outros.

A categoria Prestação de Contas precisa de duas observações importantes antes de ser analisada. A primeira é que apesar de dizerem respeito à explicação e esclarecimento sobre decisões políticas e uso de recursos, elas não trazem em seu conteúdo as informações sobre tal. Elas apenas informam para a população que isto está sendo ou que será feito, que alguns dos instrumentos de Comunicação Pública estão sendo utilizados (conselhos populares, audiências públicas, portal da transparência, orçamento participativo, governo eletrônico, conselhos gestores, centrais e serviços de atendimento ao cidadão e ouvidorias). A segunda é que a informação, por mais importante que seja figura apenas com uma pequena parcela do total analisado, com 3,4\%.

Gráfico 7 - Categorização das informações sobre Prestação de Contas

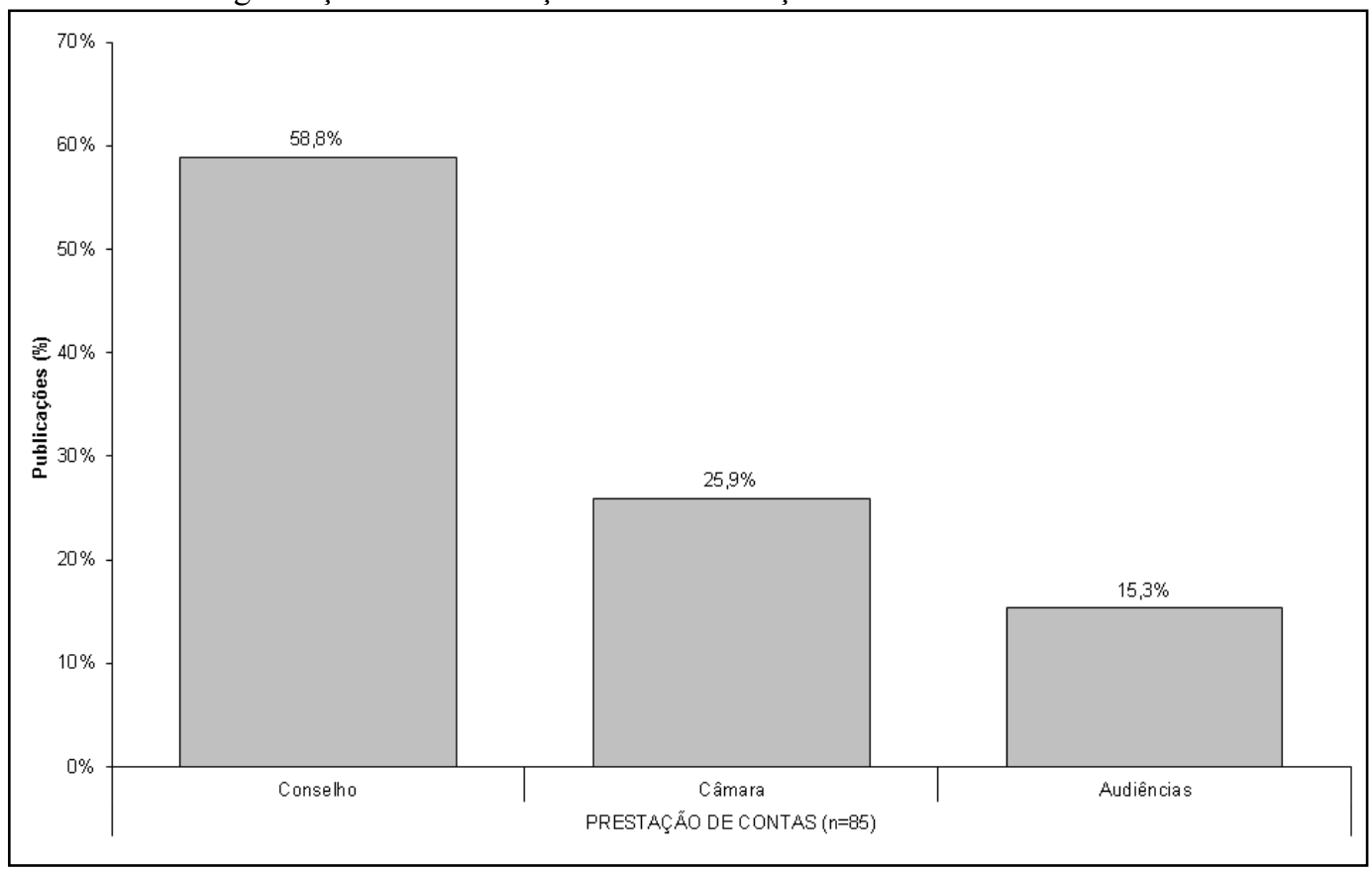

Fonte: Elaboração própria

DRd - Desenvolvimento Regional em debate (ISSNe 2237-9029) 
No item Conselho, estão agrupadas $58,8 \%$ das notícias relacionadas à prestação de contas, mas ao analisar o conteúdo, observa-se que a maioria são informações de eventos que já aconteceram ou de participação de um dirigente.

As notícias sobre a Câmara de Vereadores do Município, apesar de ser outro Poder, dotado de sua própria estrutura de Comunicação, também estão entre as minorias, com 25,9\% relativas à prestação de contas e em números absolutos, apenas 22 do total de $2535(0,8 \%)$. O conteúdo dessas informações trata de sessões especiais, mais uma vez dando destaque para a participação de um dirigente, apresentação de programas do governo, apresentação de dados para apreciação, entre outros. Ressalta-se que as notícias não possuem um enfoque de convidar a população para o debate ou apreciação das apresentações.

As notícias classificadas em Audiências trazem encontros ocorridos, sem o papel de convocar a população a participar.

Partindo para a última análise, apenas 36 das 2535 notícias categorizadas nesse estudo foram classificadas em Dados Públicos, conforme o Gráfico 8. Como dito anteriormente, esse tipo de notícia refere-se às informações de controle do estado e que dizem respeito ao conjunto da sociedade e a seu funcionamento, ou seja, são de interesse e direito de toda a população, apesar de representarem $1,4 \%$ do total selecionado. A maior parte das notícias classificadas em Dados Públicos é de dados estatísticos/balanços seguido por legislação/normas e, por fim, publicações.

Gráfico 8 - Categorização das informações sobre dados públicos

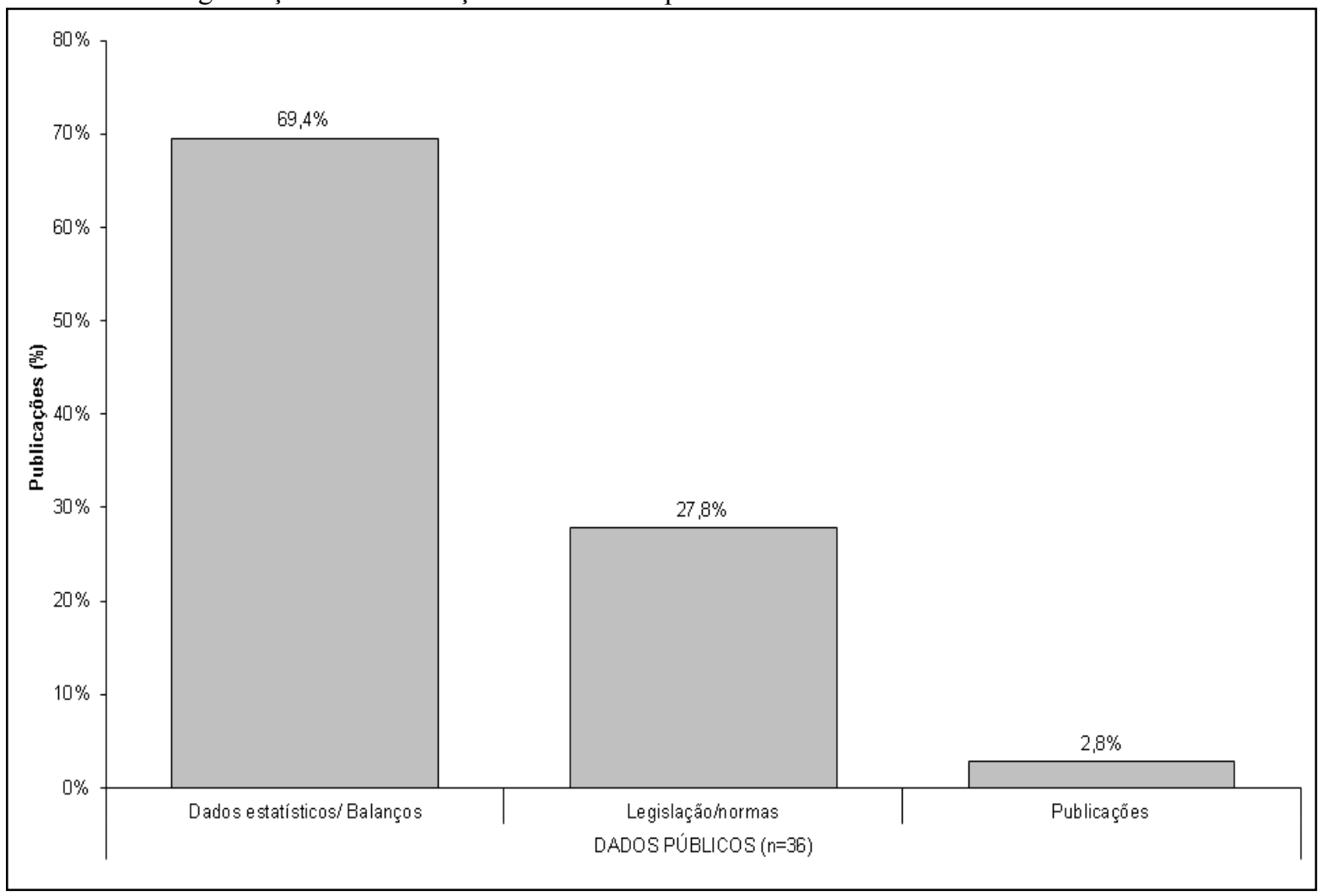

Fonte: Elaboração própria

DRd - Desenvolvimento Regional em debate (ISSNe 2237-9029) 
As notícias agrupadas em Dados Estatísticos/Balanços possuem como conteúdo número de atendimentos, número de exames realizados numa unidade de saúde do Município, valores de créditos concedidos num determinado período, balanços de ações, entre outros. Informações essas consideradas relevantes para que a população possa formar uma opinião sobre um determinado serviço ofertado, por exemplo. Para o cidadão, conseguir mensurar a eficiência de um atendimento público, torna-se decisivo o acesso a esses dados.

O item Legislação/Normas totaliza dez notícias em um universo de 2.535 (0,39\%). Parece que não é de práxis do governo informar ao cidadão, pelo menos por meio de notícia, as mudanças que ocorrem na legislação do município, as normas e procedimentos adotados, as reestruturações e reformas administrativas, as decisões judiciais tomadas ou acatadas pelo governo.

Em Publicações, houve a ocorrência de apenas uma notícia. Nesse item podemos perceber que não é hábito da Prefeitura patrocinar publicações ou ao menos de publicizar esse tipo de informação.

\section{ABUNDÂNCIA DE RECURSOS X ABUNDÂNCIA DE INFORMAÇÕES: UMA COMPARAÇÃO INEVITÁVEL}

Seria inevitável trazer para essa discussão o vultoso orçamento destinado ao Município de Campos dos Goytacazes, a maior parte dele patrocinado pelo recebimento de royalties e participação especial. Há, por certo, um questionamento rotineiro aos estudiosos sobre o tema: por que os recursos dos royalties e participações especiais, que vêm sendo sistematicamente distribuídos em grandes volumes desde 1997, não correspondem a um virtuoso desenvolvimento social para a população do Município?

Até o momento, foi conferido aos gestores maior liberdade no uso destas receitas, remanescendo as limitações atinentes ao atendimento do interesse público e observância das normas de direito financeiro e dos demais princípios gerais do direito público, sendo vedada a aplicação dos recursos em pagamento de dívidas e no quadro permanente de pessoal.

Não se pretende aqui fazer qualquer tipo de análise mais aprofundada sobre a utilização desses recursos, mas a partir da análise das informações, veiculadas em forma de notícias no Município, e exaustivamente categorizadas, percebe-se um indicativo de para aonde este recurso tem se destinado.

O Gráfico 9 nos dá uma visão geral de toda a categorização das notícias. Observa-se que as Obras e os Shows têm merecido uma especial atenção por parte dos dirigentes entre as notícias publicadas. Ora, se as notícias são pautadas de acordo com os acontecimentos, conclui-se que o esforço da Prefeitura têm sido realizar obras por todo o Município, além de promover eventos de natureza variada em grande proporção. 
Gráfico 9- Visão geral das notícias categorizadas

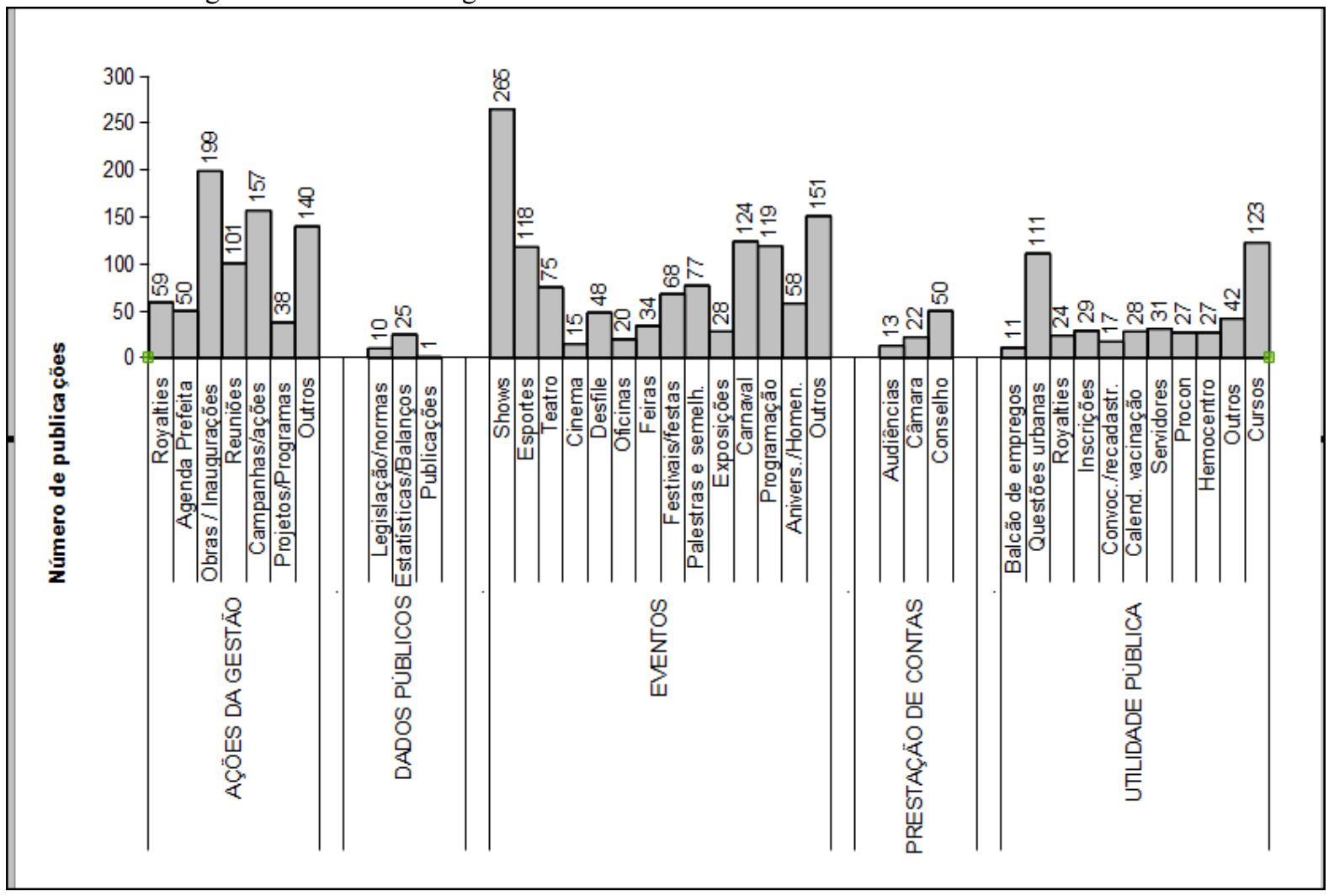

Fonte: Elaboração própria

Trazendo para a análise a Lei No 8.319, de 06 de novembro de 2012, que “estima a receita e fixa a despesa do Município de Campos dos Goytacazes para o exercício financeiro de 2013", depara-se com uma receita de R\$ 2.410.000.000,00 (dois bilhões, quatrocentos e dez milhões de reais). Lembrando-se ainda que, a mesma lei abre "créditos suplementares até o limite de 50\% (cinquenta por cento) da despesa total fixada no orçamento do município", ou seja, um "cheque em branco" com limite de mais de um bilhão de reais para o governo utilizar da forma que julgar necessário. Para Leal e Serra (2003, p. 163):

Os royalties distribuídos aos estados e municípios, têm como função equacionar um problema de justiça intergeracional, ou seja, compensá-los de uma trajetória econômica baseada em um 'recurso não renovável', por isso a necessidade de atrelar sua aplicação a investimentos pró-diversificação produtiva.

O Gráfico 10 mostra de que forma está dividida a despesa total do Município de Campos dos Goytacazes. Veja a seguir: 
Gráfico 10 - Despesa total do município de Campos dos Goytacazes para o ano de 2013

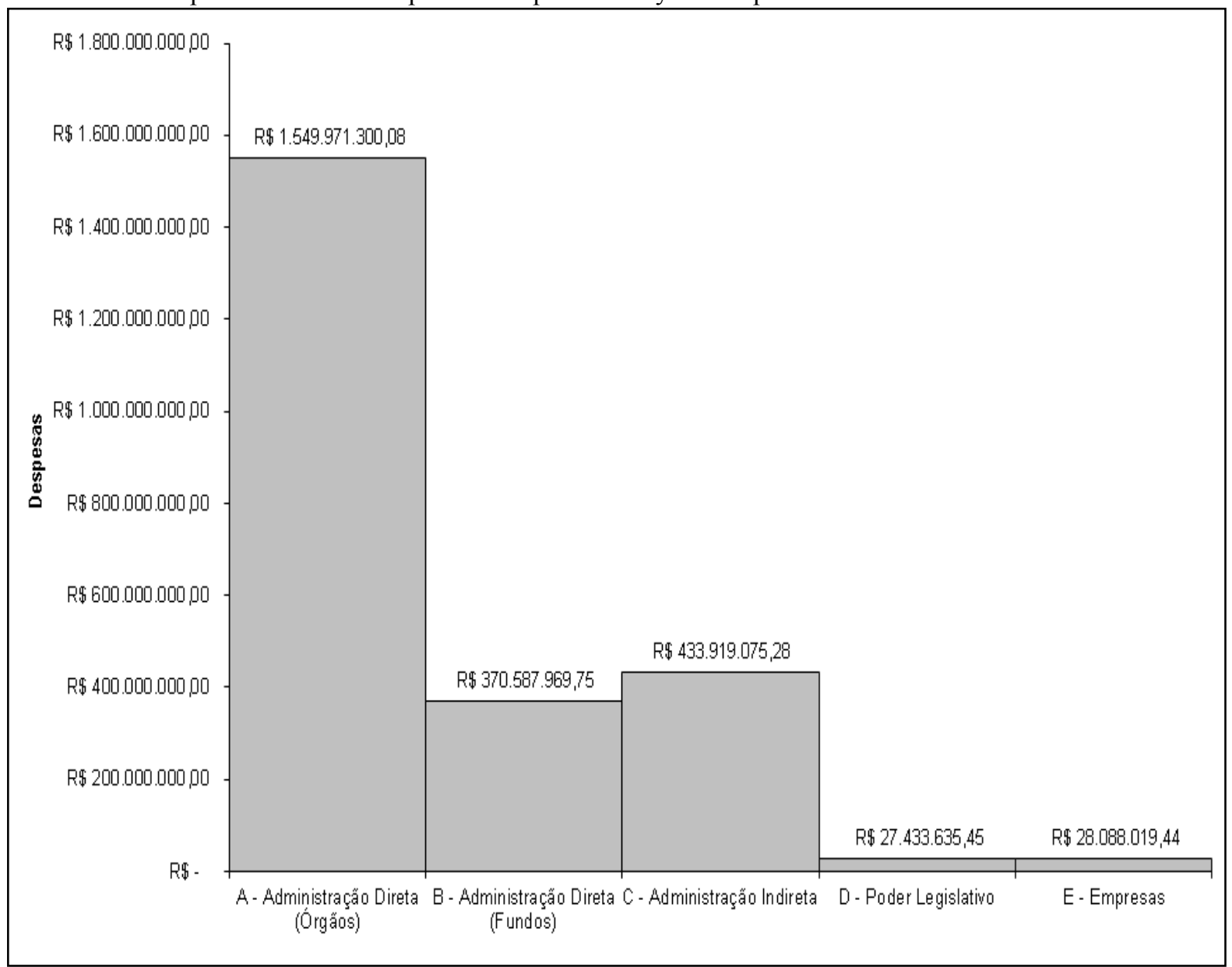

Fonte: Lei $\mathrm{N}^{\mathrm{o}} 8.319$, de 06 de Novembro de 2012

A administração direta, relativa aos órgãos, fixou uma despesa total de $\mathrm{R} \$$ 1.549.971.300,08 (um bilhão quinhentos e quarenta e nove milhões novecentos e setenta e um mil e trezentos reais e oito centavos).

A administração direta, relativa aos Fundos, fixou a despesa em R \$ 370.587.969,75 (trezentos e setenta milhões quinhentos e oitenta e sete mil e novecentos e sessenta e nove reais e setenta e cinco centavos).

Para a administração indireta, a despesa foi fixada em R\$ 433.919.075,28 (quatrocentos e trinta e três milhões novecentos e dezenove mil e setenta e cinco reais e vinte e oito centavos). A despesa do Poder Legislativo foi fixada em $\mathrm{R} \$ 27.433 .635,45$ (vinte e sete milhões quatrocentos e trinta e três mil e seiscentos e trinta e cinco reais e quarenta e cinco centavos).

E, por fim, as Empresas em Fundos Instituídos e mantidos pelo Poder Público Municipal ficaram com despesa fixada em $\mathrm{R} \$ 28.088 .019,44$ (vinte e oito milhões oitenta e oito mil e dezenove reais e quarenta e quatro centavos). 
Fazendo uma correlação com a análise central feita neste artigo, observa-se no Gráfico 11 que, assim como as informações categorizadas, as obras aparecem como figura de destaque também no orçamento, atrás da saúde e da educação, por exemplo.

Gráfico 11 - Despesa total do Município para o ano de 2013 por setor

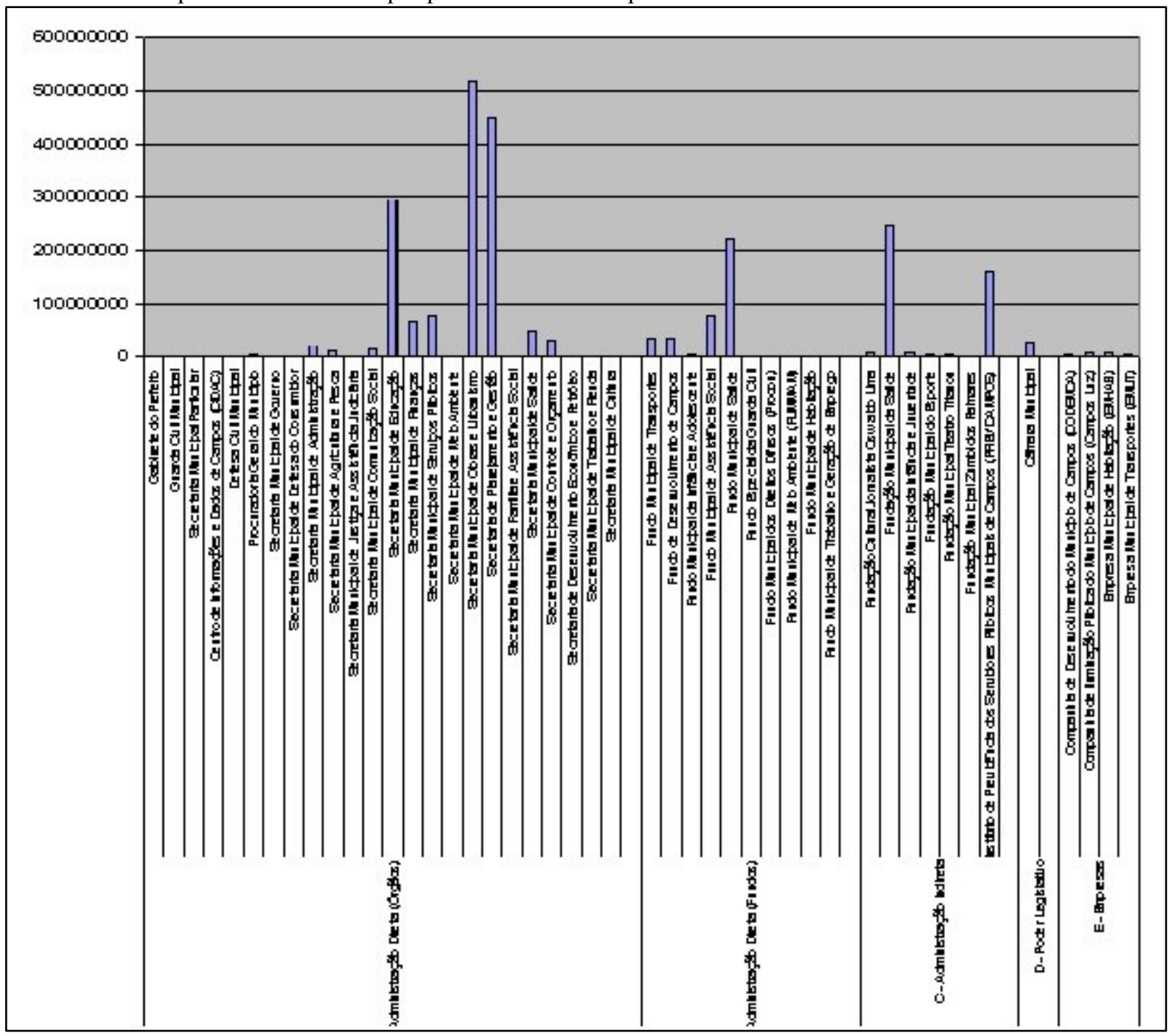

Fonte: Lei $\mathrm{N}^{\mathrm{o}} 8.319$, de 06 de novembro de 2012

Outra observação é em relação ao valor destinado as despesas da Secretaria Municipal de Comunicação de R\$14.950.000,00 (quatorze milhões novecentos e cinquenta mil reais). Percebe-se no Gráfico 12, que o orçamento da Secom é maior do que o da Secretaria de Agricultura, que tem despesa fixada em R \$ 11.900.000,00 (onze milhões e novecentos mil reais), em um Município que precisa diversificar sua economia, vem-se investindo pouco na atividade agrícola, ou melhor, pouco em relação aos demais órgãos da administração direta.

Outros exemplos também podem ser trazidos para análise, como a Secretaria de Desenvolvimento Econômico e Petróleo, que entre as atribuições está a de planejar e programar políticas diferenciadas de desenvolvimento de energias alternativas contempladas a visão de longo prazo para os setores energéticos e as perspectivas de mudanças globais de 
acesso e uso de recursos energéticos no município e tem como despesa fixa $\mathrm{R} \$ 1.000 .000,00$ (um milhão de reais). Ou a Secretaria Municipal de Meio Ambiente, com despesa fixada em $\mathrm{R} \$ 300.000,00$ (trezentos mil reais).

Gráfico 12 - Comparativo de despesas entre a Secretaria de Comunicação e as demais

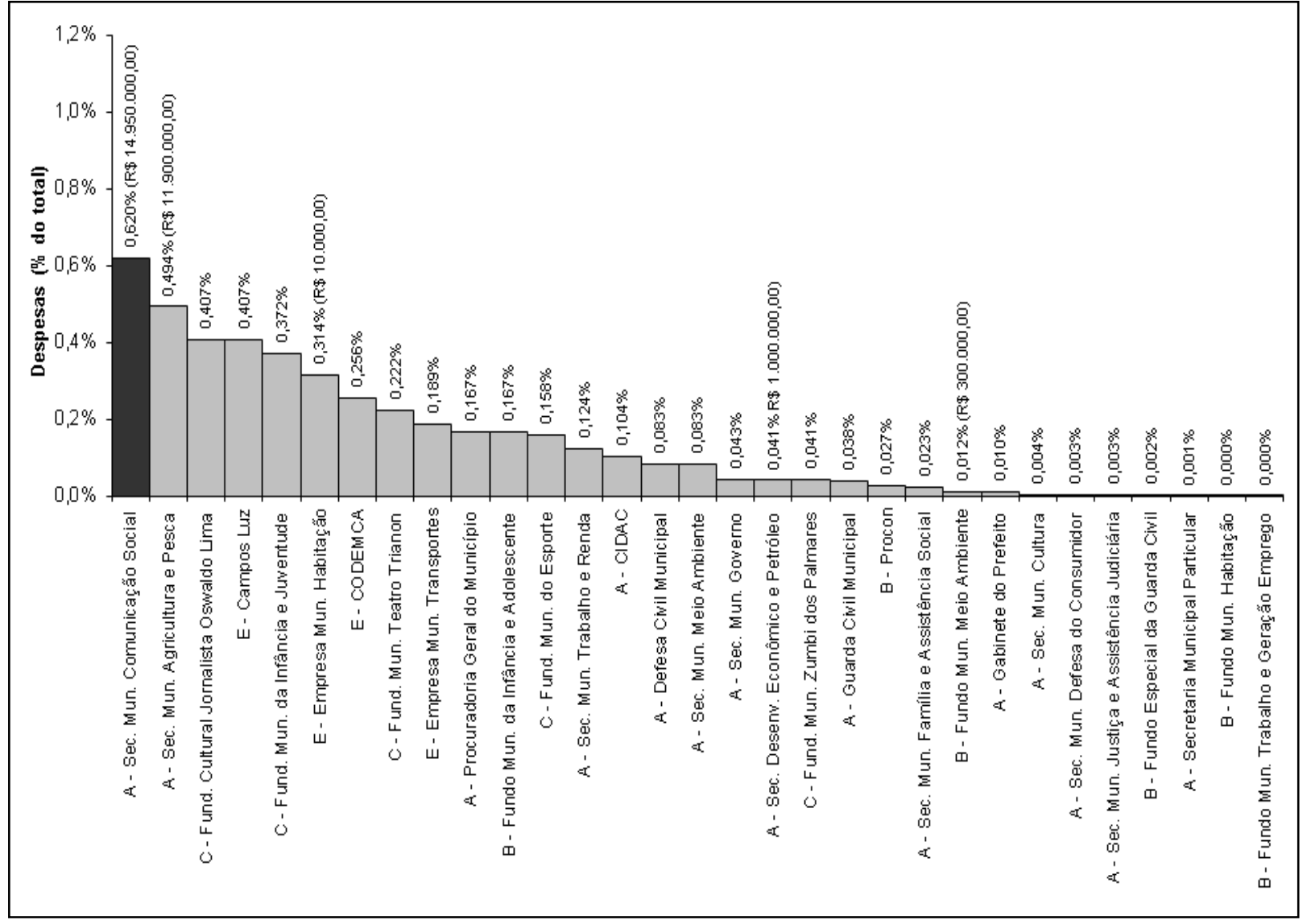

Fonte::Lei № 8.319, de 06 de Novembro de 2012.

O que se pretende com esta seção é apenas refletir sobre as seguintes questões: as informações passadas para a população têm relação com o que vem sendo prioridade no Município? São apenas notícias ou retrato do que os gestores públicos têm feito com os recursos?

Observa-se flagrante e, por vezes, um encontro entre receita, investimento e informação. Ao mesmo tempo em que a receita vem sendo direcionada para a execução de obras e o alto custo com shows gratuitos para a população, principalmente em datas festivas como carnaval, aniversário da cidade, réveillon, entre outros eventos, vê-se um grande volume de informações a respeito dos mesmos. Informações essas que não representam uma transparência por parte do governo, pelo fato de não trazer em seu conteúdo dados como valor pago, nome da empresa licitada, entre outros. 


\section{CONSIDERAÇÕES FINAIS}

O presente estudo investigou, por meio de revisão de literatura, os instrumentos que garantem o acesso à informação pública, desde a promulgação da Constituição da República Federativa do Brasil no ano de 1988, até a recente Lei $\mathrm{N}^{\mathrm{o}} 12.547$, a LAI, sancionada pela Presidente da República em 18 de novembro de 2011 e em vigor desde o dia 16 de maio de 2012. A Lei efetiva o direito previsto na Constituição de que todos têm a prerrogativa de receber dos órgãos públicos, informações de interesse pessoal e coletivo. Mas será que as administrações e os agentes públicos estão preparados para a implementação desta lei? Os desafios podem ser de natureza técnica e tecnológica, mas, além disso, é preciso que os cidadãos sejam estimulados a buscar as informações e se tornem ativos e conscientes para que garantam a participação coletiva na definição, controle e avaliação das políticas e ações públicas.

A pesquisa apontou também que a Comunicação Pública diz respeito à interação e ao fluxo de informação relacionado aos temas de interesse coletivo. Conforme Duarte (2007), mais poder para a sociedade, menos para os governos; mais comunicação, menos divulgação; mais diálogo e participação, menos dirigismo, são algumas das premissas. A respeito da Comunicação Pública e suas ramificações, a pesquisa mostrou que a Comunicação Governamental pode ser entendida como Comunicação Pública, na medida em que ela é um instrumento de construção da agenda pública e direciona seu trabalho para a prestação de contas, o estímulo para o engajamento da população nas políticas adotadas, o reconhecimento das ações promovidas nos campos políticos, econômico e social, em suma, provoca o debate público. Trata-se de uma forma legítima de um governo prestar contas e levar ao conhecimento da opinião pública os projetos, ações, atividades e políticas que realizam e que são de interesse público.

Os dados coletados no questionário respondido pelo Secretário Municipal de Comunicação nos fazem perceber uma falta de preocupação por parte do dirigente em fornecer dados mais completos, menos pontuais. Não há uma promoção da accountability, o compromisso que o gestor público deve assumir para tornar públicas informações sobre os processos e atos praticados. Nota-se ainda que a Secom está estruturada para desenvolver um trabalho de assessoria de imprensa e não de Comunicação Pública. Dessa forma, fica evidente que o objetivo é apenas divulgar as ações e promover o gestor através de notícias superficiais e factuais.

Em relação ao Portal da Transparência e Diário Oficial, ambos no site da Prefeitura, foram analisados por este trabalho. O primeiro traz informações sobre pagamentos, mas não especificam de forma clara a finalidade do gasto e em que instância foi tomada as decisões. Em suma: são dados difíceis de entender e relacionar com os serviços realizados. O segundo, apesar de publicar as decisões legais determinadas e tomadas pela Prefeitura da cidade, não faz parte do hábito de leitura do cidadão. Apesar do Secretário de Comunicação informar que o Diário Oficial também possui versão impressa, na resposta concedida a esta pesquisa, não foram especificadas a tiragem, distribuição, frequência e a forma que foi licitado.

Os dados apresentados na categorização das informações que a Prefeitura de Campos dos Goytacazes passa para a população por meio de notícias, nos leva a concluir que a 
Prefeitura prioriza informações relacionadas aos Eventos com 47,3\% (com prioridade aos shows) e às Ações da Gestão com 29,3\% (em sua maioria notícias sobre obras e inaugurações), totalizando $76,6 \%$ das notícias. Mostrando também igual importância na distribuição dos recursos públicos. Enquanto isso, apenas $18,5 \%$ das notícias trouxeram informações de Utilidade Pública. Observamos que o interesse predominante da Prefeitura não é o de abastecer o cidadão com informações para que ele usufrua melhor dos serviços ofertados e integrem o processo decisório que acompanha a prática política. As informações cumprem apenas o objetivo de apresentar e promover os serviços da administração. Mas para que ocorra bem mais que isso, é preciso questionar a aplicação dos recursos públicos que, de acordo com as informações, estão sendo prioritariamente investidos em obras e eventos.

Com a elaboração deste estudo, observa-se que a Prefeitura de Campos dos Goytacazes restringe informações públicas à sociedade por meio de notícias, deixando-os com poucos elementos para avaliar as propostas, questionar sobre os projetos e propor novas ideias aos órgãos públicos. Os serviços ofertados pelas pastas de saúde, educação, moradia e segurança, de total interesse e direito da população, já seriam suficientes para gerarem pautas que possibilitariam acompanhar o trabalho dos gestores, conhecerem os serviços e trazerem elementos para avaliar os projetos desenvolvidos pelas entidades. Transparência requer comunicar informações públicas sobre o processo, desempenho, fracassos, custos e os resultados de todas as ações desenvolvidas pelo prefeito. $\mathrm{O}$ cidadão precisa de informação para debater os assuntos da cidade o qual pertence.

Por fim, a pesquisa mostra ainda a inexistência de políticas públicas de comunicação no Município. Segundo Duarte (2007), as políticas devem ser integradas, elaboradas participativamente, propiciando o exercício de uma visão global e de uma perspectiva relativamente duradoura. Elas devem ser baseadas nas aspirações coletivas, buscando estimular a participação, o desenvolvimento da democracia, o aumento da governabilidade, o estimulo à competitividade e a integração social. É possível, por exemplo, formalizar políticas públicas em áreas como internet, acesso a dados, publicidade, radiodifusão, acesso à informação, gestão da comunicação, atendimento ao cidadão, comunicação interna, relacionamento com a imprensa.

Não é possível participação sem conhecimento. É preciso que a Prefeitura do Município de Campos dos Goytacazes assuma um compromisso com a atuação responsável no trato com as questões públicas, incluindo a oferta de informações, estímulo ao acesso, facilitação da fiscalização e a prestação de contas. A sociedade deve ter facilidade de obter informações, ser estimulada e orientada a buscá-las, a dar sua opinião, a físcalizar e a influenciar na gestão daquilo que é público. Sem isso, continuaremos distantes da superação de nossas históricas desigualdades sociais, apesar da abundância de recursos. 


\section{REFERÊNCIAS}

BARDIN, Laurece. Análise de Conteúdo. São Paulo: Edições 70, 2011.

BRANDÃO, Elizabeth Pazito. Conceito de Comunicação Pública. In: DUARTE, Jorge. Comunicação pública, estado, mercado, sociedade e interesse público. São Paulo: Atlas. 2009.

Como anda a Comunicação Pública?. In: Revista do Serviço Público. v 60, n. 2, p. 189-196, abr./jun. 2009.

BRASIL. Diário Oficial da União. Poder Legislativo. Brasília, DF, 05 jan. 1988. Disponível em: < http://legislacao.planalto.gov.br/legisla/legislacao.nsf/8b6939f8b38f

377a03256ca200686171/509f2321d97cd2d203256b280052245a? OpenDocument $>$.Acesso em: 12 jul. 2012.

Ministério das Cidades. Disponível em: $<$ http://www.cidades.gov.br/

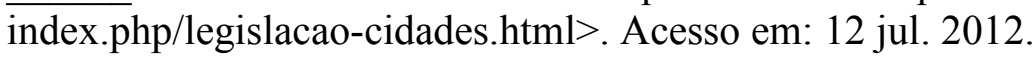

Instituto Brasileiro de Geografia e Estatísticas (IBGE). Evolução Populacional, Censo 2000 e 2010. Disponível em: <http://www.ibge.com>. Acesso em: 12 jan. 2013.

CAMPOS DE GOYTACAZES. Lei Orgânica do Município de Campos dos Goytacazes. Lei s/no de 28 mar. 1990. Disponível em: $<$ http://www.campos.rj.gov.br/listaLeis.php>. Acesso em: 12 jan. 2013.

CARVALHO, Ailton Mota de; SILVA, Roberto Cezar Rosendo Saraiva da. Formação econômica da Região Norte Fluminense. In: PESSANHA, Roberto Moraes; SILVA NETO, Romeu e (Orgs.). Economia e desenvolvimento no Norte Fluminense: da cana-de-açúcar aos royalties do petróleo. Campos dos Goytacazes, RJ: WTC Editora, 2004.

DUARTE, Jorge. Instrumentos de Comunicação Pública. In DUARTE, Jorge (Org.). Comunicação pública, estado, mercado, sociedade e interesse público. São Paulo: Atlas. 2009.

Comunicação pública. 2007. Disponível em: <http://jforni.jor.br/forni/files/ ComPublicaJDuartevf.pdf $>$. Acesso em: 18 jun. 2012.

INFOROYALTIES. Royalties e participações especiais. Disponível em: $<$ http://inforoyalties.ucam-campos.br>. Acesso em: 01 jun. 2014.

LEAL, José Agostinho; SERRA, Rodrigo Valente. Uma investigação sobre os critérios de repartição dos royalties petrolíferos. In: PIQUET, Rosélia. (Org.). Petróleo, Royalties e Região. Rio de Janeiro: Ed. Garamond, 2003. 
LIRA, Rodrigo Anido. Representação, Participação e Cooptação nos Conselhos

Municipais em Campos dos Goytacazes. Tese (Doutorado em Sociologia Política). 2012. Programa de Pós-Graduação em Sociologia Política da Universidade Estadual do Norte Fluminense Darcy Ribeiro, Campos dos Goytacazes, 2012.

MORAES, R. Análise de conteúdo. Revista Educação, Porto Alegre, v. 22, n. 37, p. 7-32, 1999.

ROCHA, D.; DEUSDARÁ, B. Análise de conteúdo e análise do discurso: aproximações e afastamentos na (re)construção de uma trajetória. ALEA, v. 7, n. 2, jul./dez. 2005.

ZÉMOR, Pierre. Comunicação pública. In: SILVA, Luiz Martins da (Org.). Algumas abordagens em comunicação pública. Brasília: Casa das Musas, 2003, p. 76-103. Versão traduzida, resumida e comentada pela Profa. Dra. Elizabeth Brandão do livro ZÉMOR, Pierre. La Communication publique. PUF, Col. Que sais-je? Paris, 1995. 


\section{APÊNDICE A - QUESTIONÁRIO}

Descrição do entrevistado: Secretário de Comunicação Social do Município de Campos dos Goytacazes

1- Nome:

2- Idade:

3- Formação e experiência profissional:

4- É servidor Público? ( ) sim （ ) Não.

5- Qual é a formação acadêmica do senhor e experiência profissional?

6- Há quanto tempo atua como Secretário de Comunicação do Município?

7- Como está estruturada a Secretaria de Comunicação do Município? São quantos servidores?

8- O senhor poderia descrever o dimensionamento da força de trabalho?

9- O município possui políticas de comunicação que norteiam as atividades da Secretaria de Comunicação? Se sim, descreva por favor.

10- As notícias publicadas no site da prefeitura são categorizadas no âmbito da Comunicação Pública?

11- Quais são os atuais volumes de recursos investidos em comunicação em Campos?

12- No portal da Transparência do município, não consta especificado na aba despesas, informações em relação aos gastos do município com Comunicação. Como dão transparência a esta área?

13- A Secretaria de Comunicação faz parte de algum Conselho Municipal? Se sim, qual conselho? Qual a periodicidade das reuniões? Poderia disponibilizar, por favor, as pautas do período de janeiro a junho de 2013 ?

14- Qual a avaliação que o senhor faz nessa articulação da Secretaria de Comunicação Social com os conselhos municipais?

15- Quais os espaços de diálogo e participação que a prefeitura mantém com a população?

16- A ouvidoria do município está ligada à Secretaria de Comunicação? Quem é o responsável?

17- Como está estruturada a ouvidoria do município e qual a assiduidade do uso desta ferramenta por parte da população?

18- Existe relatório de acompanhamento para medir o nível de participação da população e a satisfação dela em relação às dúvidas respondidas?

19- O senhor possui dados estatísticos da ouvidoria no período de janeiro a junho de 2013 que possa disponibilizar?

20- O senhor conhece a Lei $N^{0} 12.527$, denominada Lei de Acesso à Informação, sancionada pela Presidente da República em 18 de Novembro de 2011, que entrou em vigor no dia 16 de maio de 2012 ?

21- De que maneira o município está cumprindo as exigências da Lei de Acesso à Informação?

22- Os pedidos de informação por parte da população estão sendo respondidos dentro dos prazos estabelecidos pela lei?

23- Existem dados estatísticos no período de janeiro a junho de 2013 que comprovem o cumprimento destes prazos? Sem sim, poderia disponibilizá-los?

24 - Quem é responsável por garantir este cumprimento?

25- A Lei Orgânica do Município, no artigo 94, prevê que a publicação das leis e atos municipais será feita no Diário Oficial do Município e, na a falta deste, em órgão da imprensa local. Na lei, está previsto que a escolha do órgão de imprensa para divulgação das leis e atos administrativos são por meio de licitação. Nesse 
caso, se leva em conta não só as condições de preços, como as circunstâncias de freqüência, horário, tiragem e distribuição. Atualmente, o Diário Oficial do Município está disponibilizado no portal oficial da Prefeitura, no www.campos.rj.gov.br. Assim, como se deu o processo de escolha deste instrumento de divulgação que publica as decisões legais determinadas e tomadas pela prefeitura da cidade?

26 - Na opinião do senhor, toda a população de Campos tem acesso ao Diário Oficial?

27- As notícias publicadas no site da prefeitura são categorizadas no âmbito da Comunicação Pública?

28- Na opinião do senhor, a Secretaria de Comunicação está cumprindo o papel enquanto Comunicação Pública?

Artigo recebido em: 25/06/2014

Artigo aprovado em: 06/10/2014 